This Accepted Author Manuscript is copyrighted and published by Elsevier. It is posted here by agreement between Elsevier and University of Brasilia. Changes resulting from the publishing process - such as editing, corrections, structural formatting, and other quality control mechanisms - may not be reflected in this version of the text. The definitive version of the text was subsequently published in [Journal of South American Earth Sciences, Volume 17, Issue 2, October 2004, Pages 153-169, http://dx.doi.org/10.1016/j.jsames.2004.03.001]. You may download, copy and otherwise use the AAM for non-commercial purposes provided that your license is limited by the following restrictions:

(1) You may use this AAM for non-commercial purposes only under the terms of the CC-BY-NC-ND license.

(2) The integrity of the work and identification of the author, copyright owner, and publisher must be preserved in any copy.

(3) You must attribute this AAM in the following format: [agreed attribution language, including link to CC BY-NC-ND license + Digital Object Identifier link to the published journal article on Elsevier's ScienceDirect $₫$ platform].

Este Manuscrito do Autor Aceito para Publicação (AAM) é protegido por direitos autorais e publicado pela Elsevier. Ele esta disponível neste Repositório, por acordo entre a Elsevier e a Universidade de Brasília. As alterações decorrentes do processo de publicação - como a edição, correção, formatação estrutural, e outros mecanismos de controle de qualidade - não estão refletidas nesta versão do texto. A versão definitiva do texto foi posteriormente publicado em [Journal of South American Earth Sciences, Volume 17, Número 2, Outubro 2004, Pages 153-169, http://dx.doi.org/10.1016/j.jsames.2004.03.001]. Você pode baixar, copiar e utilizar de outra forma o AAM para fins não comerciais, desde que sua licença seja limitada pelas seguintes restrições:

(1) Você pode usar este AAM para fins não comerciais apenas sob os termos da licença CC- BY- NC-ND.

(2) A integridade do trabalho e identificação do autor, detentor dos direitos autorais e editor deve ser preservado em qualquer cópia.

(3) Tem de atribuir este AAM no seguinte formato: [acordo na linguagem atribuída, incluindo o link para CC BY-NC-ND licença Digital + DOI do artigo publicado na revista Elsevier ScienceDirect $₫$ da plataforma]. 


\title{
The Caldas Novas dome, central Brazil: structural evolution and implications for the evolution of the Neoproterozoic Brasilia belt
}

\author{
Luiz Jose Homem D'el-Rey Silva ${ }^{1}$ \\ Percy Boris Wolf Klein \\ Detlef Hans-Gert Walde
}

\begin{abstract}
The Caldas Novas dome (Goiaas state, central Brazil) lies in the southern segment of the Neoproterozoic Brasilia belt (center of the Tocantins Province) between the Goias magmatic arc and the margin of the ancient Sao Francisco plate. The core of the dome comprises rocks of the Meso-Neoproterozoic Paranoa group (passive margin psamitic-pelitic sediments and subgreenschist facies) covered by a nappe of the Neoproterozoic Araxa group (backarc basin pelitic-psamitic sediments and volcanics of greenschist facies, bitotite zone). Hot underground waters that emerge along fractures in the Paranoa quartzite and wells in the Araxa schist have made the Caldas Novas dome an international tourist attraction. A recent detailed structural analysis demonstrates that the dome area was affected by a $D_{1} D_{3}$ Brasiliano cycle progressive deformation in the - 750-600 Ma interval (published $\mathrm{U}-\mathrm{Pb}$ and Sm-Nd data). During event $D_{1}$, a pervasive layer- parallel foliation developed coeval the regional metamorphism. Event $D_{2}$ (intense $F_{2}$ isoclinal folding) was responsible for the emplacement of the nappe. $D_{1}$ and $D_{2}$ record a regime of simple shear (top-to-SE relative regional movement) due to a WNW-ESE subhorizontal compression $\left(\boldsymbol{a}_{1}\right)$. Event $\mathrm{D}_{3}$ records a WSW-ENE compression, during which the dome rose as a large-scale $F_{3}$ fold, possibly associated with a duplex structure at depth. During the dome's uplift, the layers slid back and down in all directions, giving way to gravity-slide folds and an extensional crenulation cleavage. A set of brittle fractures and quartz veins constitutes the record of a late-stage $D_{4}$ event important for understanding the thermal water reservoir.
\end{abstract}

Keywords: Caldas novas dome; Brasilia belt; Brasiliano cycle; Neoproterozoic; Structural analysis; Thermal water; Tocantins province

\footnotetext{
${ }^{1}$ Instituto de Geociências/Universidade de Brasilia (IG/UnB), Campus Universitário Darcy Ribeiro, Asa Norte, CEP 70,910-900 Brasilia-DF, Brazil
} 


\section{Introduction}

The Caldas Novas dome (Goiás state, central Brazil) is a structural window in the central part of the Neoproterozoic Tocantins Province, a N-Strending, double-verging orogen between the Amazon and Sao Francisco cratons, bounded by the Parana and Parnaiba Phanerozoic basins (Fig. 1a). According to a summary in D'el-Rey Silva and Barros Neto (2002), the Araguaia and Brasilia belts reflect the collision of the Sao Francisco and Amazon ancient plates ca. 650-600 Ma ago (Brasiliano cycle), whereas the Paraguay belt records a 550-500 Ma old inversion of a rift opened in the former Amazon plate and filled 600-550 Ma ago. The Brasilia belt, in which there is also evidence of a 800-700 Ma old tectonic event, actually comprises the Goias mag matic arc and internal and external zones (MA, IZ, and EZ; Fig. 1b).

Around the parallel of the federal district (Fig. 1b), the Brasilia belt trends NE in its northern segment and SE in its southern segment. The bend is roughly coincident with the Pirineus shear zone, a nearly E-W- striking zone of high strain that affects rocks of the MA, IZ, and EZ up to the federal district. Farther east, the EZ is in contact with the Meso-Neoproterozoic sedimentary cover of the Sao Francisco craton (Marini et al., 1984; Fuck et al., 1993; 1994). Polyphase Neoproterozoic deformation in the MA, IZ, and EZ is largely characterized by frontal ramps and E-verging thrusts and folds. The easternmost remnants of two major nappes that displaced higher metamorphic grade rocks of the $I Z$ onto the lower metamorphic grade rocks of the EZ are found up to the surroundings of Brasilia (Fig. 1b). The Araxa, Passos, Luminarias, and Socorro-Guaxupe nappes constitute the main tectonic features of the southern end of the belt (Fig. 2). 


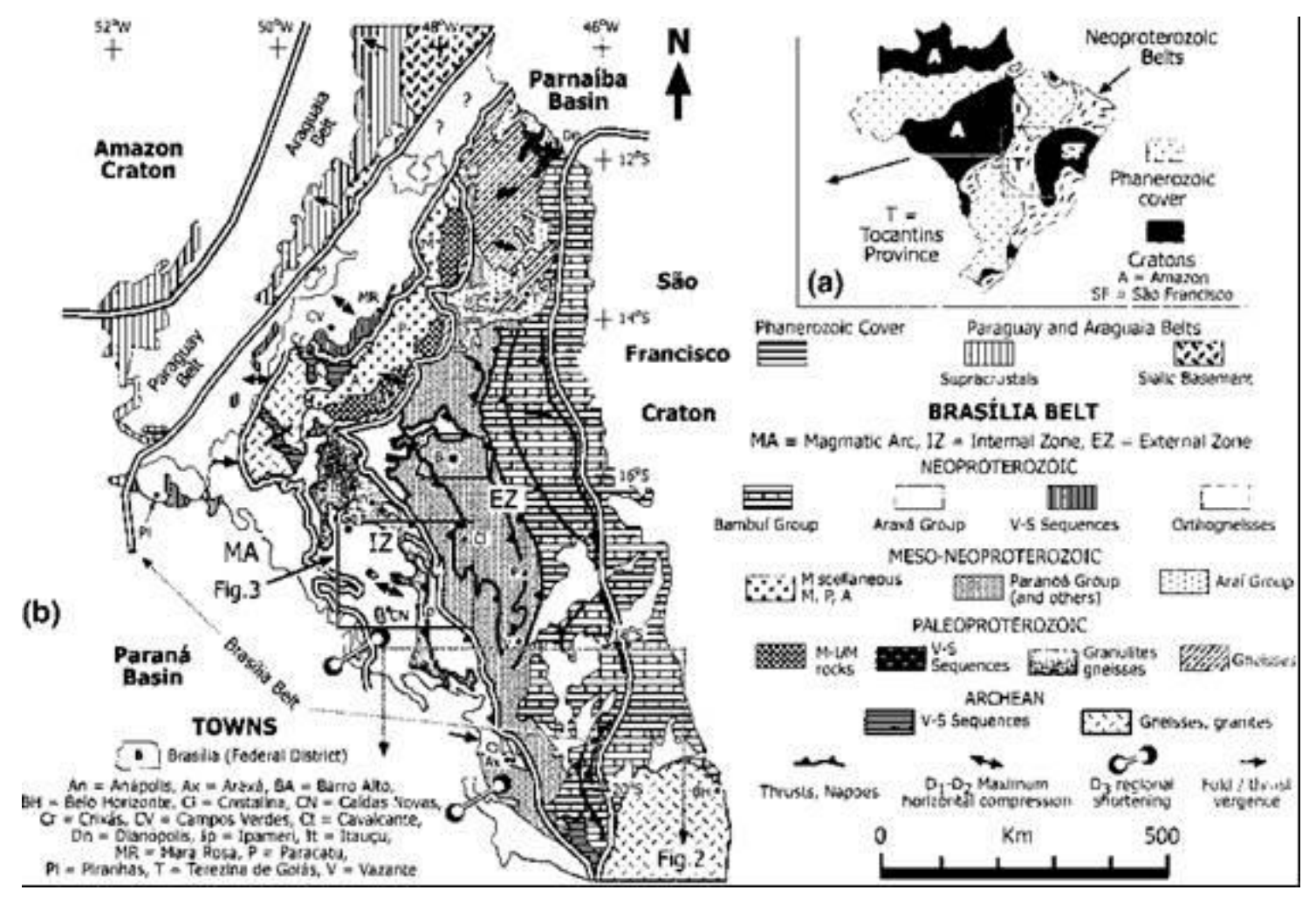

Fig. 1. (a) Simplified map displaying the major lithotectonic units of Brazil and highlighting the Tocantins Province between the Sao Francisco and Amazon cratons. (b) Simplified geological map of the central part of the Province, based on Marini et al. Marini et al. (1984), Fuck et al. (1993, 1994), and Pimentel et al. (1999, 2000). Vectors for maximum horizontal compression $\left(O_{1}\right)$ are according to a vast inventory of lithostructural data (D'el-Rey Silva and Barros Neto, 2002). Direction for $D_{3}$ shortening is based on this paper and Seer and Dardenne (2000).

Although the Caldas Novas dome is well known for its thermal waters, few international publications (e.g. Drake, 1980; Troger et al., 1999) discuss its geology, and the most comprehensive general and recent study of the dome, which remains unpublished, does not address a structural analysis (Campos et al., 2000). Since 1999, a Brasilia University-Technical University of Berlin research program has provided additional information on the regional hydrology. Further data on the geology and water chemistry appear in technical reports sponsored by DNPM (a federal office) and local companies (e.g. UHECorumba, Geocaldas, Geocenter).

In this article, we summarize the results of a structural analysis carried out in the Caldas Novas dome area in October-December 2000. We provide a structural database relevant for understanding the regional geology and underground reservoirs of hot water. All data are integrated into a model that accounts for the tectonic evolution of the dome and the physical-chemical 
characteristics of the hot water reservoirs. Our results, combined with the results of previous and independent structural analyses, geological mapping, and age determination shed light on the critical difference between the two segments of the Brasilia belt, a challenge for any interpretation of the tectonic evolution of Tocantins Province.

\section{Tectonic setting}

\subsection{The magmatic arc (MA), internal zone (IZ,) and external zone} (EZ)

The MA, originally characterized by Pimentel and Fuck (1992), consists of tonalitic orthogneiss, granites, and volcanic-sedimentary sequences (Lacerda Filho et al., 1999), but it remains poorly known in the north (Pimentel et al., 2000). The IZ includes, in its northern segment, an ArcheanPaleoproterozoic continental block of gneiss, tonalite, and greenstone-type volcanic-sedimentary sequences affected by polycyclic tectonism (Queiroz, 2000); three mafic-ultramafic layered intrusions metamorphosed to the granulite facies (plus metavolcano- sedimentary sequences to the west, not distinguished in Fig. 1b) and narrow tectonic slices of Paleoproterozoic basement rocks to the east; and a strip of metasediments that comprises, from $S$ to N, rocks of the Araxa, Paranoa, and Serra da Mesa groups (Fig. 1b; D'elRey Silva and Barros Neto, 2002). In the south, the IZ includes the backarc basin-like Araxa group, which mainly comprises amphibolite-greenschist facies metasediments and basic metavolcanics (e.g. Brod et al., 1991) and a longitudinal belt of Neoproterozoic granulites. The eastern boundary of the IZ is a contractional frontal ramp that dips less than $30^{\circ}$ to the west and places high$P$ rocks in sharp contact with the Araxa nappe, as well as with low greenschist facies and strongly shortened passive margin-like metasediments of the EZ (Fig. 1b). 


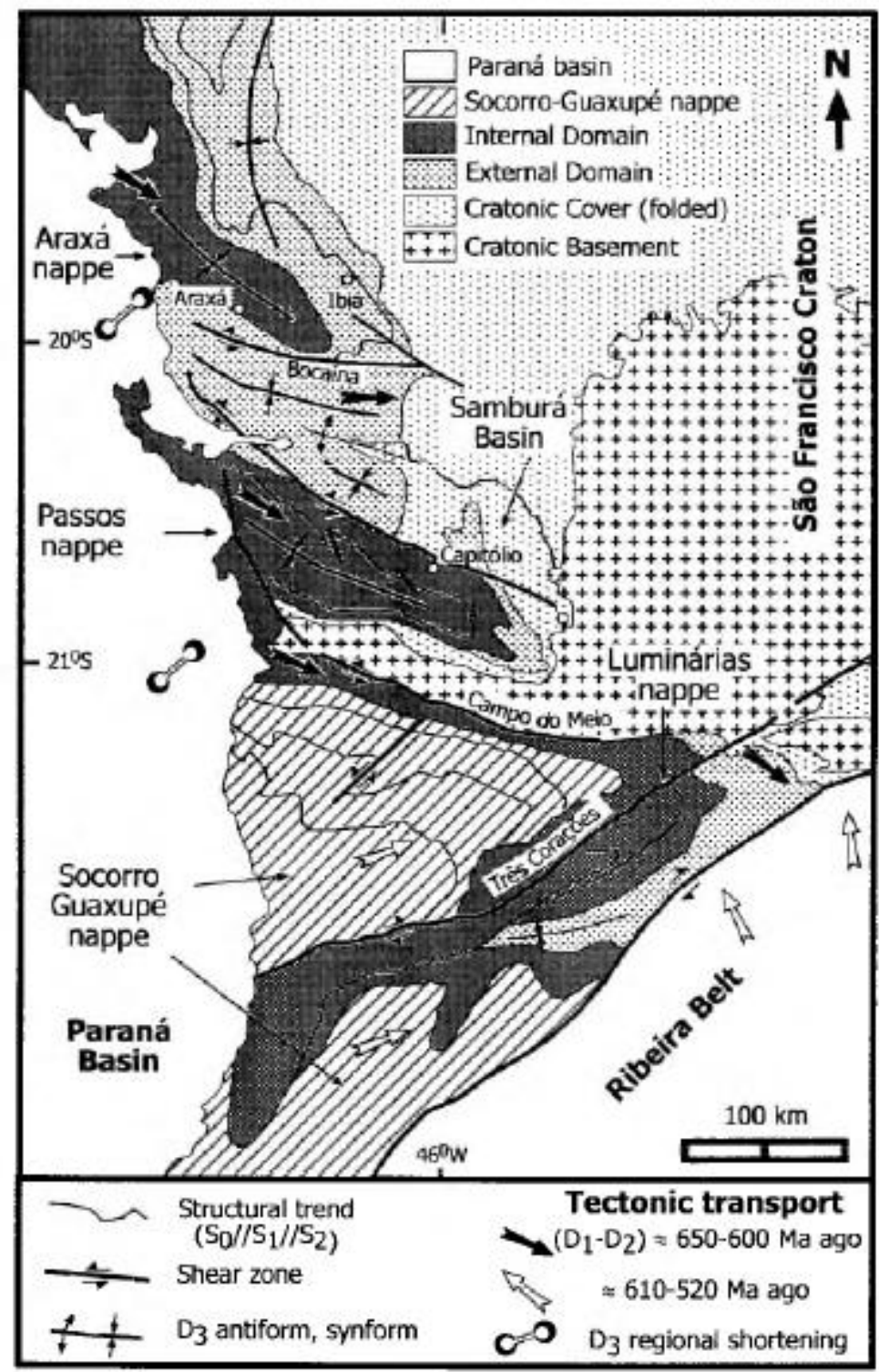

Fig. 2. Simplified geological map of the southern segment of the Brasilia belt (based on Valeriano et al., 2000, with addition of $D_{3}$ shortening direction). The Araxa, Passos, and Luminarias nappes displaced rocks of the IZ to the ESE onto the EZ during $D_{1}-D_{2}$ and were lately shortened in the ENE direction (the $D_{3}$-related Araxa and Passos synforms and intervening antiforms). Emplacement of the Socorro-Guaxupe nappe system onto the Passos and Luminarias nappes followed in time and occurred in the same overall ENE direction.

The EZ comprises, from $\mathrm{N}$ to $\mathrm{S}$, Archean/Paleoproter- ozoic basement rocks and Meso-Neoproterozoic, sub-greenschist to amphibolite facies metasediments and metavolcanics. The younger rocks include the Mesoproterozoic rift basin-like Aral group (metasiliciclastics and metavolcanics), which correlates with the Serra da Mesa group; the passive margin-like MesoNeoproterozoic

Paranoa and Canastra groups (metasiliciclastic and metacarbonate sediments; calc-schist, metapelite, and quartzite) and the Neoproterozoic Ibia 
and Vazante groups (respectively, siliciclastics and fine-grained silici- clastics and metacarbonates); and the Bambui group (siliciclastic and carbonate metasediments), which rests on the Paranoa group along the eastern margin of the EZ and stretches over the Sao Francisco craton.

\subsection{Surrounding the Caldas Novas dome}

The area surrounding the Caldas Novas dome displays north-trending tectonic slices of a frame of Brasiliano cycle frontal ramps and intervening lateral ramps (Fig. 3). Data in Lacerda Filho et al. (1999), Fischel et al. (1998, 1999a-c) and Pimentel et al. (1999, 2000) indicate a general lithostratigraphy consisting of a Paleoprotreozoic crystalline basement (gneiss, orthogneiss, and the Silvania metavolcano-sedimentary sequence); a Meso-Neoproterozoic cover that includes the Paranoa, Canastra, and lbia groups; and a large set of Neoproterozoic rocks that includes metasediments of the Araxa and Ibia groups, metavolcano-sedimentary sequences termed Rio Veríssimo and Marata, orthogneiss of the Goias MA, granulitic rocks akin to the AnapolisItaucu complex that occurs outside the area to the north of Leopoldo de Bulhoes, and the Ipameri, Aragoiania, and Rio Piracanjuba granite suites.

The area also includes elongated bodies of (mylonitic) granitic intrusions syntectonically emplaced in the Araxa supracrustals (Pimentel et al., 2000; not individualized in Fig. 3). They comprise the subvolcanic Marata granites (, 794 $\mathrm{Ma}$ old, U-Pb data) derived from the Paleopro- terozoic continental crust, as well as 700-780 Ma old ( $\mathrm{Rb}-\mathrm{Sr}$ data) granites, which display strongly and slightly peraluminous signatures, respectively. The former also occurs in the Marata area, east of Pires do Rio (Fig. 9 in Pimentel et al., 1999), and has an Sm-Nd composition with ${ }^{\mathrm{t}} \mathrm{dm}$ model ages in the 1.73-2.5 Ga interval, similar to that of the Araxa metasediments. The latter are Sesmaria- and Tambu-type granites, with main outcrop areas east of Ipameri along the Araxa-lbia contact (Fig. 10 in Pimentel et al., 1999). These granites derive from Neoproterozoic juvenile material with $\mathrm{Sm}$ - $\mathrm{Nd}$ model ages of 1.1-1.0 Ga, equivalent to that found in the adjacent Goias MA (Pimentel et al., 2000). 
The Caldas Novas dome area is particularly important because it lies in the southern part of a granulite belt that includes (Fig. 1b), three M-Um intrusions (granulitized ca. $780 \mathrm{Ma}$ ago) and the Anapolis-Itaucu complex extending south of Ipameri (east of Caldas Novas). Granulites of this complex derive from supracrustals and granites, are aged ca. $603 \pm 31$ and $633 \pm 28 \mathrm{Ma}$, according to U-Pb data in garnets and zircons (Fig. 1b; Fischel et al., 1999a,b; Fischel, 2002) and occur tectonically intercalated within lower metamorphic grade rocks of the ca. $750 \mathrm{Ma}$ old Araxa nappe. According to these authors, both high- and low-grade rocks display similar Sm-Nd isotopic signatures. To provide a mechanism to explain the uplift of the granulites of the $I Z$ and their field relationship with the lower-grade metasediments of the nappe and the EZ, D'el-Rey Silva et al. $(1996,1997)$ and D'el-Rey Silva (2002a) have shown that the contraction of the EZ post-nappe emplacement must have occurred through the mechanism of underthrusting, with the upper crust accompanying the wetward ductile flow of the ancient Sao Francisco plate. 

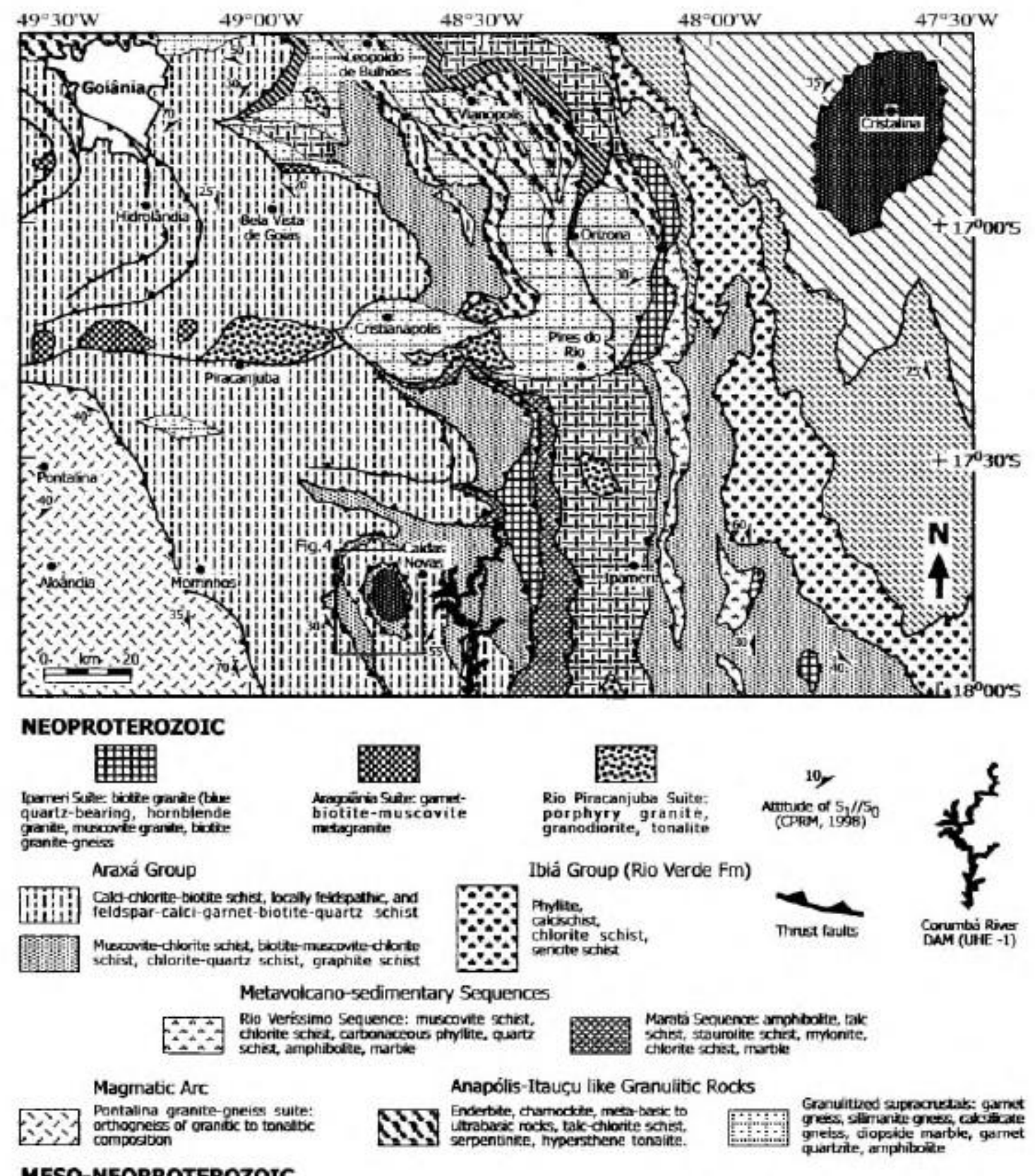

\section{MESO-NEOPROTEROZOIC}

\section{Canastra Group}

Fisty carbonaceos ptrlite with thin quartite

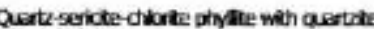
intercalations

\section{ARCHEAN-PALEOPROTEROZOIC}

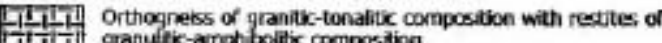
-

\section{Paranoá Group (indifferentiated)}

Quartite, carboeaceous phylthe, mctaratutone, claycy

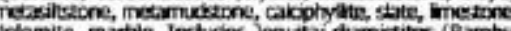
colomite, marpie, Inctuces jequit,

Fig. 3. Simplified geological map of the southern segment of the Brasilia belt in the surroundings of the Caldas Novas dome (inside the study area, Fig. 4) based on Lacerda Filho et al. (1999), Fischel et al. (1998, 1999a-c) and Pimentel et al. (2000). The subdivision and the vertical succession of the Neoproterozoic rocks are informal and do not imply any relative age relationship. 


\section{Summary geology of the Caldas Novas dome area}

\subsection{Summary lithostratigraphy}

The Caldas Novas dome is a $-20 \times 12 \mathrm{~km}$ elliptic structure, with its longer axis trending NNW (Fig. 4). The study area includes Proterozoic tectonites of the Paranoa and Araxa groups. The former occupies the core of the dome, whereas the latter surrounds it and spreads in all directions. Undeformed conglomerates of a local body (Fig. 4) have been assigned to the Cretaceous Areado group (Campos et al., 2000).

In the study area, the Paranoa group is a psamo-pelitic sequence comprising four lithostratigraphic units found in normal contact (Campos et al., 2000). The basal unit consists of commonly white, wavy rippled, cross-stratified orthoquartzite that is silicified and crops out along the internal border of the dome but is partially covered by younger laterite (omitted in Fig. 4) in the central part.

Five drill holes along an E-W cross-section prove the continuity of the quartzite, at least at depths of up to $100 \mathrm{~m}$. Moreover, gravity data indicate a negative anomaly (Haraly, 1978, 1980) that indicates that the Paranoa group (lighter material) extends to $1000 \mathrm{~m}$ deep underneath the dome. Above, the basal orthoquartzite passes to a unit of brown to red, argillaceous, immature, and commonly laminated quartzite; then to intercalated layers of quartzite and metasiltstone (a metarhythmite unit); and finally to an upper unit of metasiltstone, metamudstone, and argillous metasiltstone.

The Araxa group consists mainly of schists or layered sequences of mica schist, quartzite, siltic schist, metapelite, pelitic metasiltstone, or metasiltstone. The thicknesses of these layers may vary within $\mathrm{dm}$ - to $\mathrm{m}$ - or even dam-scales. Slightly or unweathered schist commonly exhibits a greyish green color, and the schist layers display a basic mineralogy of chlorite, biotite, muscovite, and quartz combined in variable percentages across the area. Feldspars may occur in the matrix, but no feldspar grain was found in the field, even with the aid of a hand lens. Nevertheless, $\mathrm{cm}$-size flakes of white mica are relatively common 
(e.g. outcrops 2, 68, 72). In several outcrops closer to the contact with the Paranoa rocks around the dome (e.g. 33, 37, 38, 39, 50, 57, 66, 67, 70), the bottom of the group consists of biotite-quartz schist, biotite-quartzite, and chlorite-biotite-schist that forms a continuous layer resistant to erosion. Small bodies of ultramafic rocks also have been identified regionally within the Araxa group (Drake, 1980), as well as in the SW corner of the study area (omitted in Fig. 4 Campos et al., 2000).
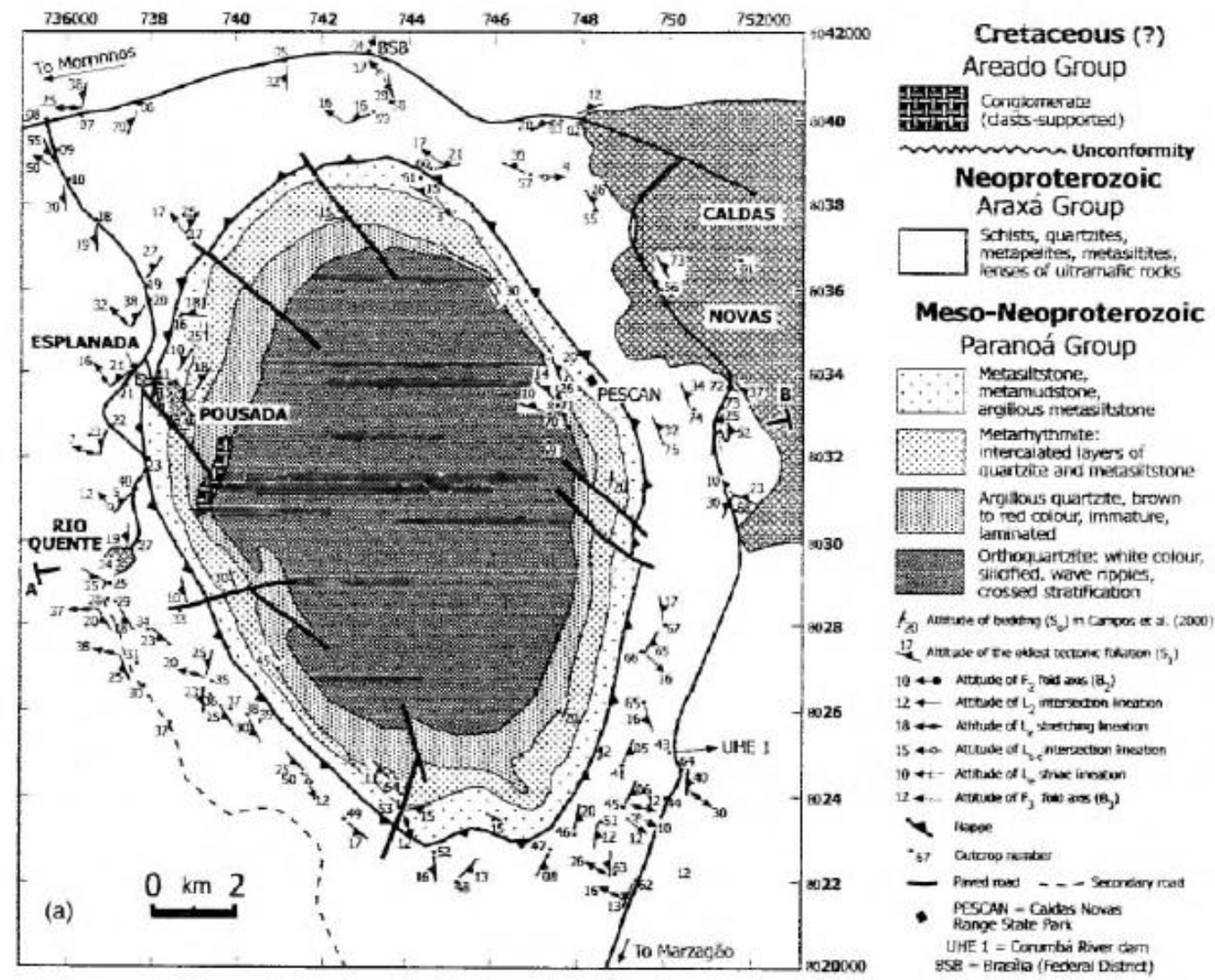

Meso-Neoproterozoic Paranoá Group

$\therefore$ Metasitstone, metamudatone, Metartyrnmite:
intercalated ijers of
aluatcite and inesasstston

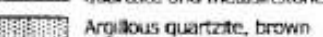
III to red colour, immature,

mon Orthoquartate: white colo 1. Shiched. Wave nppicis

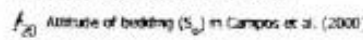

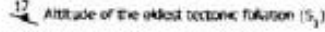

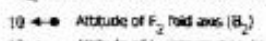

124 Arode af $\mathrm{L}_{2}$ mersotion inouton

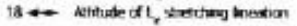

15 4. Allude of be meraxtion theation

10 ta- Nethate of I, the imsen

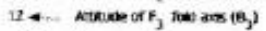

4 rowe

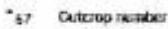

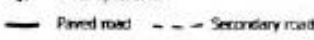

- pescan - Caudas Novios Range srate pari UHE 1 = Corumbi River dam
gSR - Bracila (Federai Ditnd)

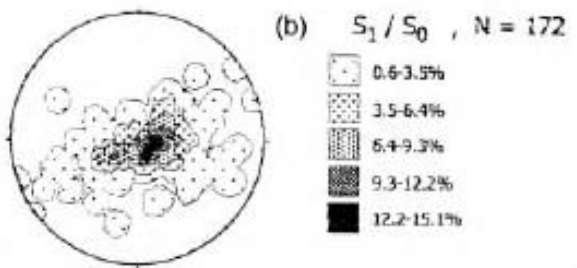

(c) $\quad \mathrm{S}_{2} / \mathrm{AP}, \mathrm{N}=87$

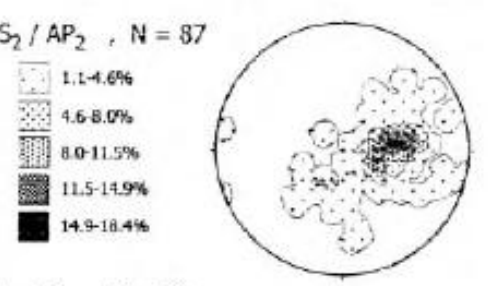

(d) $L_{x}+L_{8}, N=29=20+9$

(e)

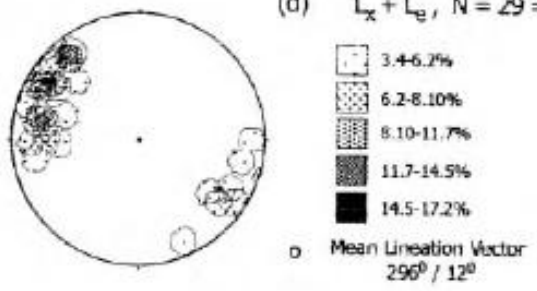

$L_{2} \cdot B_{2}, N=76$

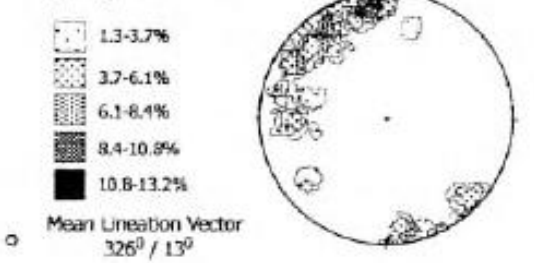

Fig. 4. (a) Simplified geological map of the studied area displaying some of the main $D_{1}-D_{2}$ foliation and lineation data. All overburden has been omitted. Main towns are Caldas Novas, Esplanada, and Rio Quente. The approximate limits of a major tourist park (Pousada) are also shown. Location of the roads is approximate between two successive outcrops, 
particularly those far from one another. Line $A B$ stands for the cross section in Fig. 12. Lower hemisphere stereograms (Schmidt-Lambert net) of structural data are in b-e.

\subsection{Underground Waters}

Thermal waters have been noted in the region of Caldas Novas since the beginning of the eighteenth century (Oriente, 1982). The first site was found along a stream that started in a fracture zone and cross-cut quartzites of the western flank of the dome and passed into Pousada park. From here, the stream turns into the Rio Quente, which flows through Esplanada (Fig. 4) with a rate of $1.4 \mathrm{~m}^{3} / \mathrm{s}$ of water as hot as $38{ }^{\circ} \mathrm{C}$ but becomes colder to the west. According to Zschocke (2000), there are three kinds of underground water reservoirs surrounding Caldas Novas: (1) the Paranoa aquifer whose thermal waters $\left(>51^{\circ} \mathrm{C}\right.$ ) flow from open fractures in the low greenschist metamorphic facies quartzites, (2) the Araxa aquifer whose thermal waters $\left(>41^{\circ} \mathrm{C}\right.$ ) have been explored from the Araxa schists; and (3) a porous aquifer consisting of cold waters $\left(24^{\circ} \mathrm{C}\right)$ in the lateritic cover.

Since the early 1970s, Caldas Novas has been a tourist site, benefiting from the activities of the numerous hotels and private clubs established in the city with pools of thermal waters from more than 400 boreholes made in the Araxa schist. Tourism currently also spreads into localities to the west of the dome and has caused a new wave of civil construction and tourism jobs. The intensive exploration of the thermal waters has driven DNPM toward more restrictive control in an attempt to avoid misuse of the underground resources.

\subsection{Summary of deformation events and associated structures}

The area displays clear evidence of a progressive (Brasiliano cycle) evolution during three ductile to ductile-brittle deformation events $\left(D_{1}-D_{3}\right)$ that affect the primary layering $\left(\mathrm{S}_{0}\right)$, defined by the intercalation of beds of different composition and easily recognizable at different scales in Paranoa and Araxa metasediments. The inventory of structures includes folds, such as $F_{2}$ and $F_{3}$, three axial-plane foliations $\left(S_{1}-S_{3}\right)$, fold axes $\left(B_{2}\right.$ and $\left.B_{3}\right)$, and lineations such as the intersections of $S_{2}$ with $S_{0}$ and $S_{1}$ and stretching and striae lineation $\left(L_{2}, L_{x}\right.$, 
and $L_{e}$ ). The Araxa schists also display two extensional crenulation cleavages $\left(c^{0}\right.$ and $\left.d^{0}\right)$. Approximately five sets of brittle fractures $\left(S_{4}\right)$ have been recognized, some of which may host $\mathrm{cm}$ - to $\mathrm{dm}$-thick quartz veins.

Events $D_{1}$ and $D_{2}$ record a progressive simple shear along frontal ramps and imply a relative top-to-ESE displacement along surfaces subparallel to $S_{0}$ that gently dip to the NW. The $D_{1}$ event developed the pervasive layeringparallel $S_{1}$ foliation, but metamorphism is more intense in the Araxa rocks (biotite zone, greenschist facies) than in the Paranoa rocks (subgreenschist facies). The $D_{2}$ event is responsible for the placement of higher metamorphic grade Araxa rocks as a nappe on the lower-grade Paranoa group. The Araxa group displays many isoclinal to tight $F_{2}$ folds of $\mathrm{cm}$ - to $\mathrm{dm}$-scale, whereas Paranoa rocks exhibit $F_{2}$ folds that are $\mathrm{dm}$ - to $\mathrm{m}$-scale and commonly isoclinal to tight. Further slip resulted in the development of the $c^{0}$ extensional crenulation cleavage, which records progressive displacement within Araxa schists with systematic top-down to various directions between NE and SE. The $D_{3}$ event developed a major, NNW-SSE-trending, double-plunging $F_{3}$ antiform (i.e. the dome itself) that also affected the nappe.

\section{Main tectonic structures}

\section{1 $D_{1}$ event of deformation}

Event $D_{1}$ mostly developed the $S_{1}$ foliation and probably the $F_{1}$ folds as well. Drake (1980) assumes that such folds occur, though they are hard to find and impossible to measure because they were so severely flattened that no hinge can be recognized. In areas where deformation records a progressive inter- and intralayer flow, as in Caldas Novas, $F_{1}$ folds may not develop; therefore, $F_{1}$ should be recognized as just those folds that are actually refolded by $F_{2}$ folds or cross cut by $S_{2}$ foliation.

Foliation $S_{1}$ is penetrative and subparallel to the primary bedding. In the Araxa rocks, $S_{1}$ is commonly a mylonitic structure that consists of a cm-scale $S$ -C pair in the schists or a mineral foliation in relatively coarser-grained silici- 
clastic layers. The S-C mylonitic structure also may be identified in some intercalated quartzite layers. Almost everywhere, the S-C asymmetry indicates a top-to-ESE relative movement. The intersection lineation may be safely measured only locally, due to the $S$ and $C$ planes in $\mathrm{S}_{1}\left(\mathrm{Li}_{\mathrm{S}-\mathrm{C}}\right)$; therefore, it has not been treated statistically. The Araxa schist commonly displays $\mathrm{cm}$-thick and $\mathrm{dm}$-long plate-like quartz veins subparallel to the $S$ or $C$ foliations of the pair $S$ $C=S_{1}$. Such plates are useful for identification of $F_{2}$ folds, foliations $c$ ! and $d^{0}$, and $L_{e}$ striae lineation. In the Paranoa rocks, $S_{1}$ is more commonly a mineral foliation defined by fine-grained white mica and flattened quartz in quartz-rich layers or very fine-grained mica (sericite) in phyllites or layers with greater clayey components. The stereogram for $S_{1} / S_{0}$ (Fig. $\left.4 b\right)$ shows not only a clear dispersion along the center of the diagram, but also a girdle that reflects the influence of the $F_{2}$ and $F_{3}$ folds. Despite all this deformation, the maximum concentration of poles still records gentle dips to the W or WNW.

\section{2 $\mathrm{D}_{2}$ event of deformation}

Event $D_{2}$ developed the $F_{2}$ folds, the axial plane $S_{2}$ foliation, the penetrative $L_{2}$ lineation, and the $B_{2}$ fold axis. The stretching lineation $\left(L_{x}\right)$ and extensional crenulation cleavage $\left(c^{0}\right)$ relate to both $D_{1}$ and $D_{2}$ events. Foliation $\mathrm{S}_{2}$ (commonly a mineral foliation or, more locally, a slaty cleavage) is less prominent than $S_{1}$ but is also penetrative. Fine-grained flakes of sericite and chlorite (less muscovite) and flattened crystals of quartz define $S_{2}$ in Araxa rocks, whereas sericite and flattened quartz do so in Paranoa rocks. The slaty cleavage consists of closely spaced planes of partition and is more common in fine-grained Paranoa rocks, even quartzites. The mineralogy and small grain size of micas along $S_{2}$ indicate that $D_{2}$ is associated with a low greenschist facies metamorphism.

The $F_{2}$ folds are cm- to dm-scale in outcrops of Araxa schists and up to $10 \mathrm{~m}$ scale in the Paranoa rocks. They are commonly tight to isoclinal, gently to moderately inclined, or even recumbent, and often evolve into sheath folds (Fig. $5 \mathrm{a}$ and $\mathrm{b})$. The latter are key features to decipher the tectonics in the area, in that they keep a constant orientation and clearly define a generally down-dip 
stretching direction $L_{x}$ with a strong striae lineation $\left(L_{e}\right)$. Although the $F_{2}$ sheaths are observed directly in the mica schists (e.g. Fig. 5b, outcrops 25,45 ), they are more commonly seen in Araxa schists that contain large amounts of $\mathrm{S}_{1}$-parallel plate-like quartz veins. In some localities, the quartz plates are remnants of thin quartzite layers commonly encountered in the Araxa metasediments (e.g. Fig. 5). The plates of quartz also may display a strong striae lineation parallel to the axis of the $F_{2}$ sheath, a few centimeters apart (e.g. outcrops $25,35,45)$. This evidence justifies the interpretation that the striae indicate slip along the stretching direction; therefore, $L_{x}$ and $L_{e}$ data could be included in a single stereogram (Fig. 4d).

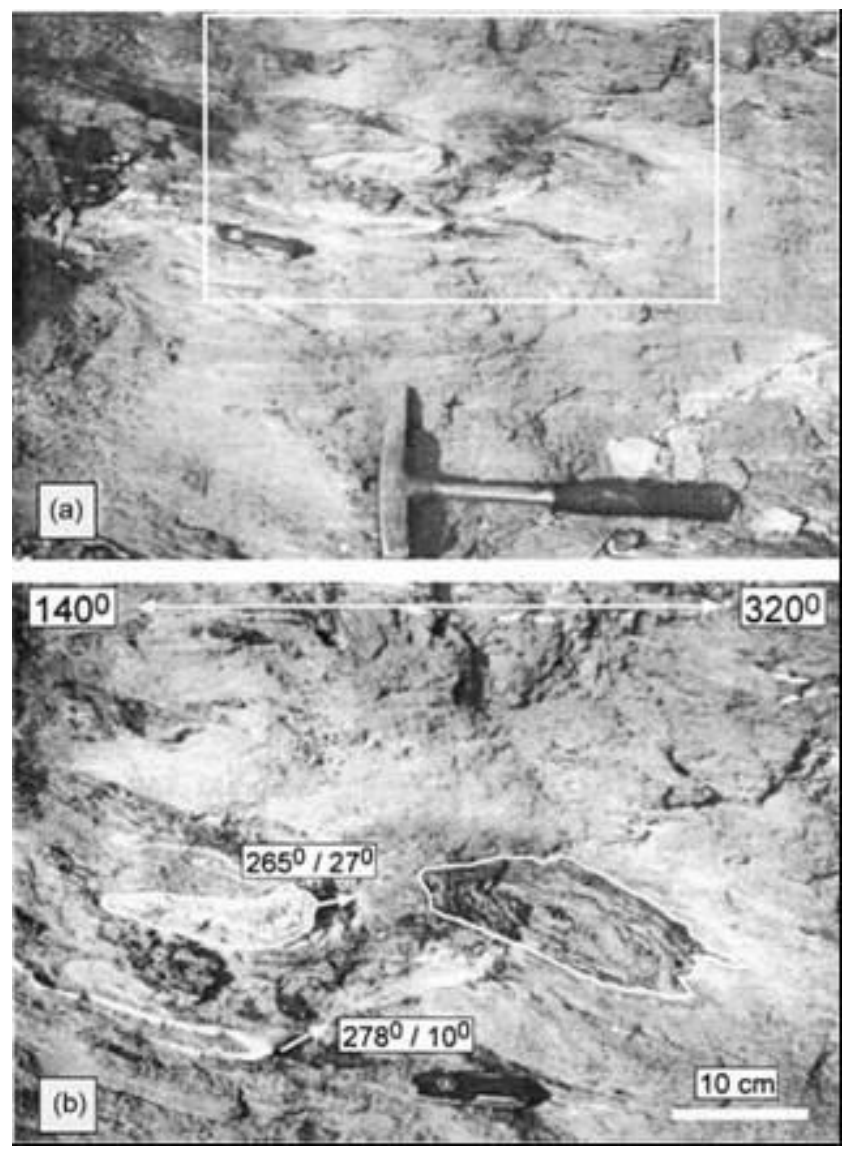

Fig. 5. (a) Isoclinal $F_{2}$ folds affecting Araxa siltic schist (outcrop 22, $W$ of the dome, Fig. 4) in which primary layering $\left(S_{0}\right)$ is defined by intercalation of $\mathrm{cm}$-thick layers and is parallel to a penetrative schistosity $\left(\mathrm{S}_{1}\right)$. The rectangle area is in the detail (b) and displays two dm-size elliptic structures defining the tubes of $F_{2}$ sheaths, the one to the right developed in the mica schist. Axes of $F_{2}$ folds (arrows) are parallel to the tube axis (attitudes are shown) and down-dip on the $S_{1}$ planes.

The $\mathrm{F}_{2}$ sheaths are also found in Paranoa rocks at a dm- to m-scale (e.g. outcrops 26, 53,54). The stereogram for $\mathrm{S}_{2}$ and $\mathrm{AP}_{2}$ (Fig. 4c) is similar to that 
for $S_{1} / / S_{0}$, which indicates that such planes are nearly parallel in the field because the $F_{2}$ folds are frequently isoclinal. In areas where this situation is common, the term $L_{x}$ applies because it is impossible to distinguish whether tectonic slip took place during $D_{1}, D_{2}$, or both events. The distinction is clear where actual $F_{2}$ sheath folds are observed, but the striae observed on a plate of quartz likely developed progressively and probably record the net slip from both events.

Both $B_{2}$ and $L_{2}$ both plunge to a fan of directions that includes three main populations (Fig. 4e). The first is the same for $L_{x}$ (Fig. $4 d$ ) because of the $F_{2}$ sheathing process. The second (and smallest) population indicates axes that plunge shallowly to the SW, according to the few $F_{2}$ folds preserved in their original trend. The third and largest population indicates plunges of $B_{2}$ and $L_{2}$ to the N-NNW or S-SSE, which result from the incomplete rotation of $B_{2}$ from the SW (original trend) to the direction of maximum stretching (WNW). Thus, the mean lineation vector (326\% 13\%; Fig. 4e) differs slightly from the average $L_{x}$ $\left(296 \% 12^{\circ}\right.$; Fig. 4d). 

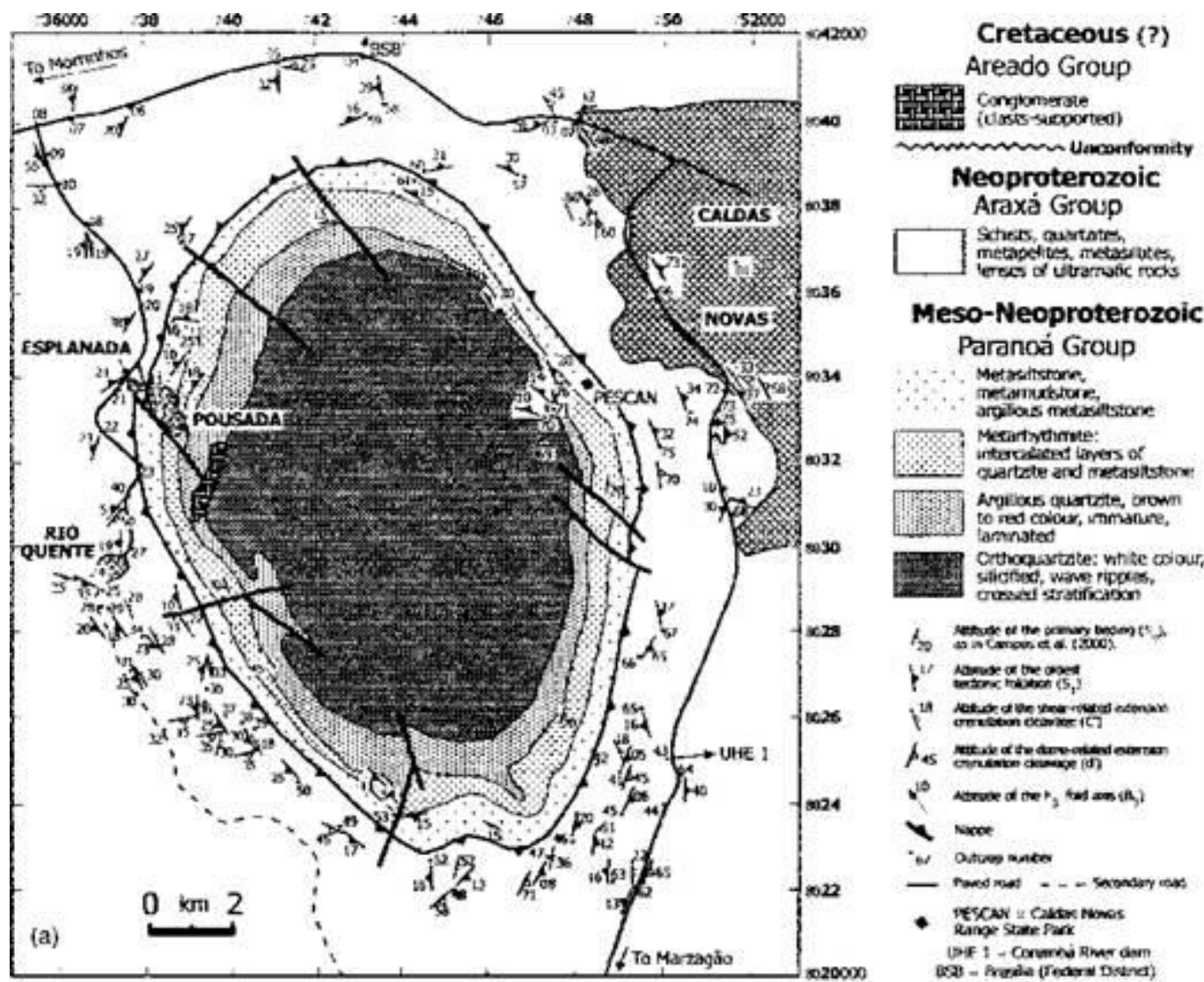

Meso-Neoproterozoic Paranoá Group Metrsitstare. metanublure,
argisous metasiltstone Merartydimute: intorcheed limers of guartete and retcasitstors: Apoioss quartite, orown to red colour, nnmanue,

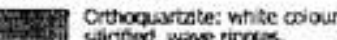

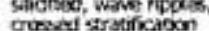

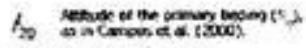

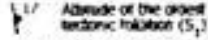

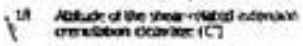

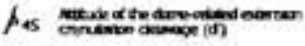

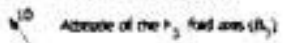

$y$.

is ationsones

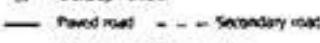

- rescar y cantas noms

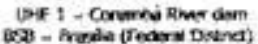

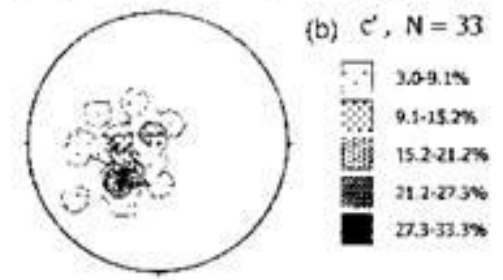

(c) d', N $=39$

(d) $S_{3}-A P_{3}, N=39$

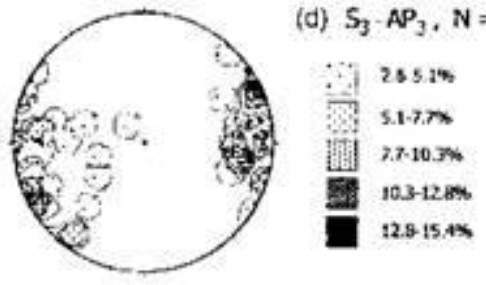

F.T. 25.5.2\%

(9.1-27\%

대요 $310 \%$

整 10312.85

12815.46

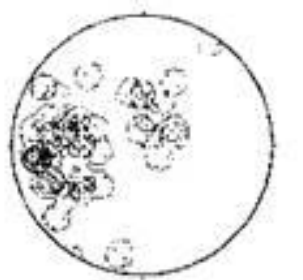

(e) $B_{3}-L_{3}, N=42$
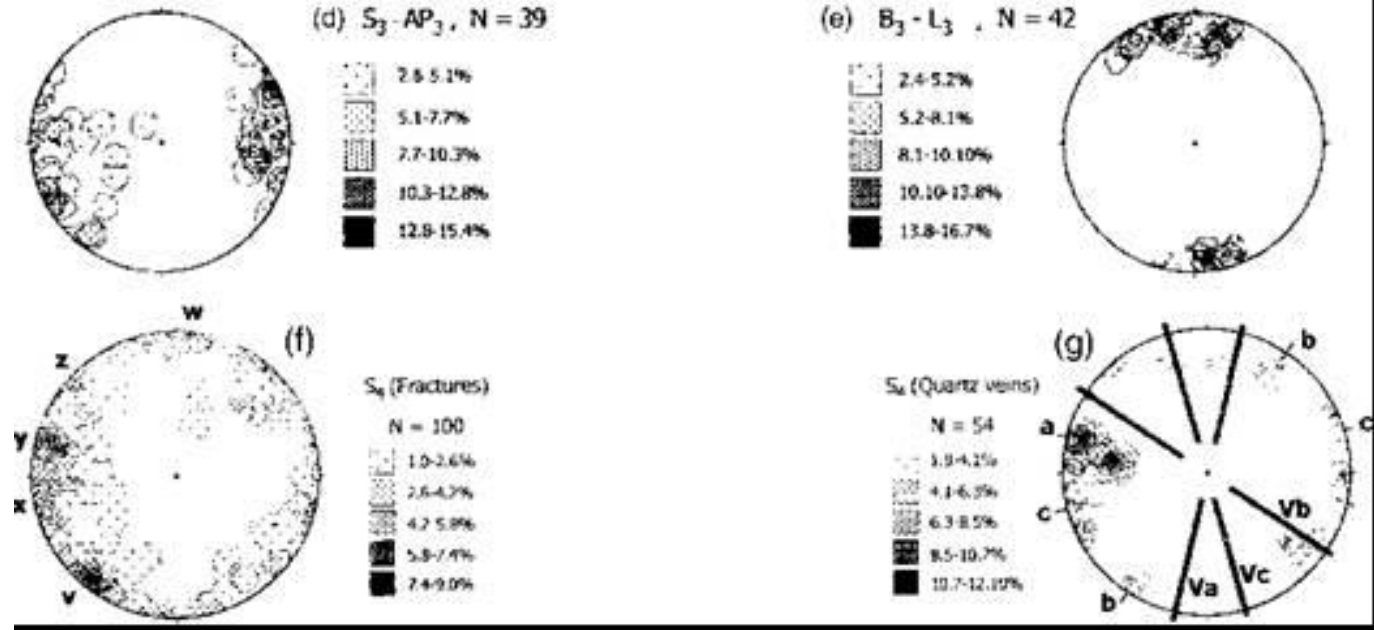

Fig. 6. (a) Same map as in of Fig. 4 displaying the main foliation $\left(\mathrm{S}_{1} / \mathrm{S}_{0}\right)$ and the two extensional crenulation cleavages $(\mathrm{c} 0, \mathrm{~d} 0)$ that affect $\mathrm{S}_{0} / / \mathrm{S}_{1}$ in the study area. Lower hemisphere stereograms (Schmidt-Lambert net) of structural data are in b-g. 
The $S_{1}$ data from Fig. 4a are plotted on a map (Fig. 6a) with the other main foliation in the area $\left(\mathrm{c}^{0}, \mathrm{~d}^{0}\right)$, whereas other data for brittle fracturing and quartz veining are plotted in Fig. $6 \mathrm{~b}-\mathrm{g}$. The extensional crenulation cleavage $\mathrm{c}^{0}$ is common in the Araxa mylonitic schists, both inside and outside the study area, such as in outcrops along the road to Ipameri and to the east of the Corumba River (Fig. 3). Foliation $\mathrm{c}^{0}$ consists of subparallel, discontinuous, slightly curved surfaces (not rarely anastomosed) that strike at a high angle with the direction of $L_{x}$ and dip gently to moderately to the east (Fig. 6b). The $c^{0}$ planes affect the S-C foliation and make it a sigmoidal-shaped feature, which suggests top- down to easterly directions (Fig. 7). The discontinuous nature of $\mathrm{c}^{0}$ is a key feature that distinguishes it from $\mathrm{d}^{0}$ planes. Discontinuity occurs because $c^{0}$ surfaces start and die along planes (foliation c) close to one another, which resembles the $c^{0}$ structure described by Lister and Snoke (1984) for progressive extension during the evolution of SC mylonites in general. Planes of $c^{0}$ formed during $D_{1}$ and $D_{2}$; they are observed displacing $F_{2}$ folds in the Araxa schists (Fig. 7).

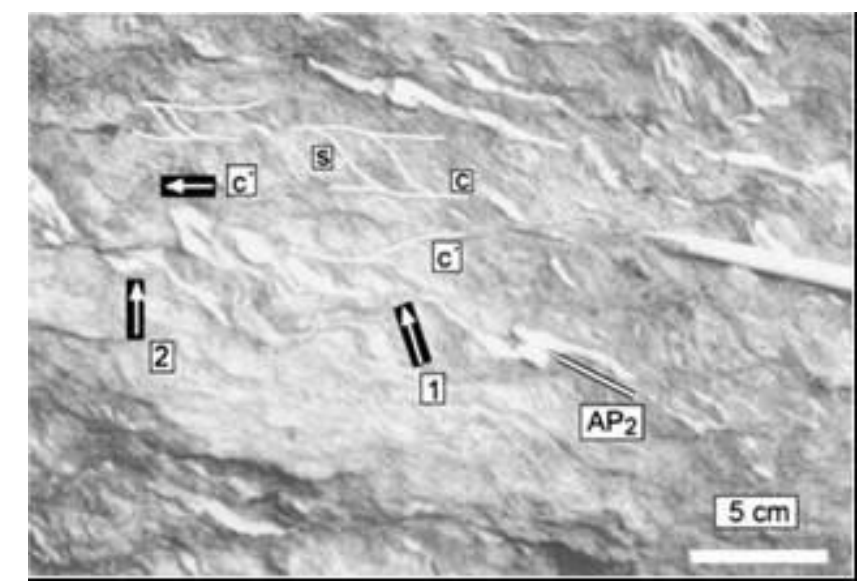

Fig. 7. The syn- $D_{x} / D_{2}$ extensional crenulation cleavage $\left(c^{0}\right)$ affects the Araxa mylonitic schist and is observed everywhere in the area. It affects a typical S-C pair ( $=S_{1}$ foliation) or even $F_{2}$ folds in several dam- to hm- scale outcrops $\mathrm{W}$ and $\mathrm{E}$ of the dome. Photograph taken in outcrop 35. Arrows 1 and 2 indicate foliation $\mathrm{c}^{0}$ displacing quartz veins that had been affected by $F_{2}$ folds.

\section{3 $D_{3}$ event of deformation}

The structures described in this section $\left(S_{3}, F_{3}\right.$, and $\left.d^{0}\right)$ relate to the uplift of the Caldas Novas dome. This event not only modified the dip of $D_{1}-D_{2}$ structures around the NNW-SSE-trending axis of the dome, but also moved the 
layers down, mainly to the $\mathrm{E}$ and $\mathrm{W}$ directions, but also to the NE, NW, SW, and SE.

Foliation $S_{3}$ is a spaced or crenulation cleavage, generally marked by very fine-grained sericite, that commonly occurs as the axial planar cleavage of $F_{3}$ folds. These folds are open to tight, steeply inclined to upright, and subhorizontal to gently plunging and indicate a WSW-ENE shortening during $D_{3}$. This interpretation, justified by the constant and consistent orientation of both $\mathrm{S}_{3} / / \mathrm{AP}_{3}$ and the fold axis B3 (Fig. $6 \mathrm{~d}$ and e) is positively tested against other data from the regional geology. The $F_{3}$ folds display varied style, scale, and vergence due to two basic processes that may be attributed to their formation: a late- $D_{2}$ progressive slip along $S_{0}-S_{1}$ and $S_{2}$ planes (continuation of the $D_{1}-D_{2}$ inter- and intralayer shearing) and gravity sliding.

The $F_{3}$ folds formed by inter- and intralayer shearing include (1) open to tight folds of $10 \mathrm{~cm}$ scale, upright or steeply inclined, east-verging, with crenulation-style that refold $F_{2}$ isoclinal folds (e.g. outcrop 02 for Araxa, 54 for Paranoa rocks); (2) gentle folds of $10 \mathrm{~m}$ - or greater scales found far from the dome, such as east of Caldas Novas, along the road leading to Ipameri; and (3) tight, $10 \mathrm{~m}$ scale folds that occur in outcrops 68 and 73 (Figs. 4a and 6a) and indicate a $\mathrm{km}$-scale $\mathrm{F}_{3}$ fold affecting the Araxa schist to the east of the dome, with a fold axis nearly N-S (to the east of PESCAN, Fig. 6). The western limb of the major $F_{3}$ fold east of PESCAN is affected by upright, $10 \mathrm{~cm}$ scale $F_{3}$ crenulations oriented similar to the larger fold, as seen in outcrops 68,73 , and 74. Farther south, between the road to Marzagao and the dome (Fig. 6a), the Araxa layers that dip toward one another (see outcrops 62, 63, and 65 and their relationship to surrounding outcrops) suggest the existence of other km-scale $F_{3}$ folds. The same finding is valid south of the dome (outcrops 48 and 52). For all these folds (measured or deduced), the fold axis $B_{3}$ plunges to the NNW or SSE (Fig. 6e). The $F_{3}$ folds, due to gravity sliding, appear on the western and eastern sides of the dome. Those on the western side include 10-100 m scale, WNW-verging folds (Figs. 8 and 9 ) that affect $D_{1}$ and $D_{2}$ structures and display vergence compatible with a top-to-the-WNW shear, in contrast to the sense implied by $D_{1}-D_{3}$ structures in general. The fold shown in Fig. 8 lies closer to 
the dome and displays layers that underwent intense brecciation during folding. Those on the eastern side include, among others, m-scale folds found in the Paredao outcrop.

Foliation $d^{0}$ is an extensional crenulation cleavage that extended $D_{1}-D_{2}$ structures, according to $\mathrm{mm}$ - to cm-scale displacements, top-down to the south, east, or north (Fig. 6a). Foliation $d^{0}$ does not occur to the west or northwest of the Caldas Novas dome (Fig. 6c), other than the specimen that dips to the $\mathrm{S}$ in outcrop 10 (Fig. 6a). As will be discussed subsequently, this is a key feature for understanding the origin of $\mathrm{d}^{0}$ and the dome. Foliations $\mathrm{d}^{0}$ and $\mathrm{c}^{0}$ look very similar, which suggests compatibility in the conditions of ductility and metamorphism that prevailed during their evolution. Nevertheless, there are key and subtle differences that distinguish extensional crenulation cleavages as $\mathrm{d}^{0}$ or $c^{0}$ in outcrops. Whereas $c^{0}$ surfaces are typically sigmoidal shaped and their trace is only visible for few centimeters, foliation $d^{0}$ is defined by more discrete and planar surfaces that are continuous for nearly $1 \mathrm{~m}$ or more (Fig. 10). In flatlying or 3D outcrops where both foliations occur (e.g. 36, 37, 38, 41, 47, 62, 75), their distinctive characteristics are evident, and $d^{0}$ is always steeper than $c^{0}$.

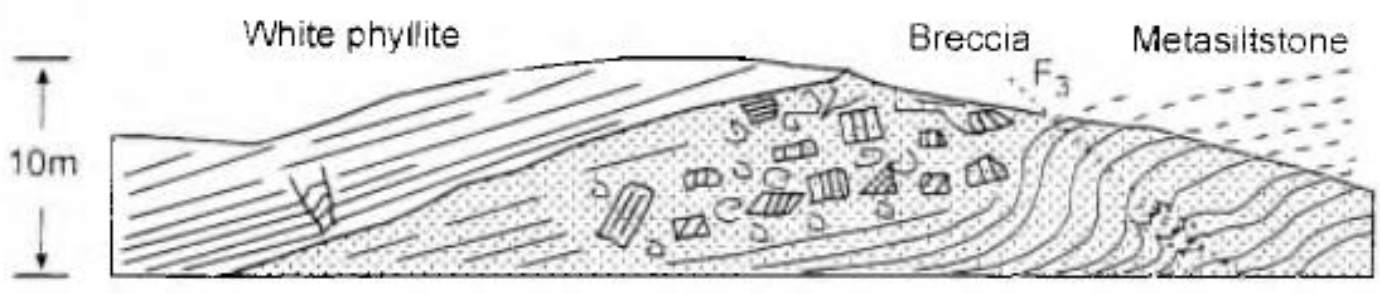

Fig. 8. Sketch displaying information collected during a detailed observation along a nearly $80 \mathrm{~m}$-long, $10 \mathrm{~m}$-high, manmade wall situated behind the tennis courts in Pousada park (outcrop 15). Basal metasiltstone layers topped by white phyllite dip gently to NW and display foliation $S_{1}$ (not shown) subparallel to $S_{0}$. A steeper mineral foliation $S_{2}$ (not shown) cross-cuts $S_{1} / / S_{0}$ at low angle and dips westward. These rocks and structures are affected by a $10 \mathrm{~m}$-scale and $\mathrm{NW}$-verging $\mathrm{F}_{3}$ fold in the SE part of the outcrop. The metasandstone layers were disrupted around the hinge of the fold, and the fragments underwent chaotic rotation to form a breccia. This fold indicates a top-to-the-WNW down-dip movement compatible with a $\mathrm{m}$-scale, kink-style $F_{3}$ fold seen in the phyllite in the leftmost part of the outcrop. 


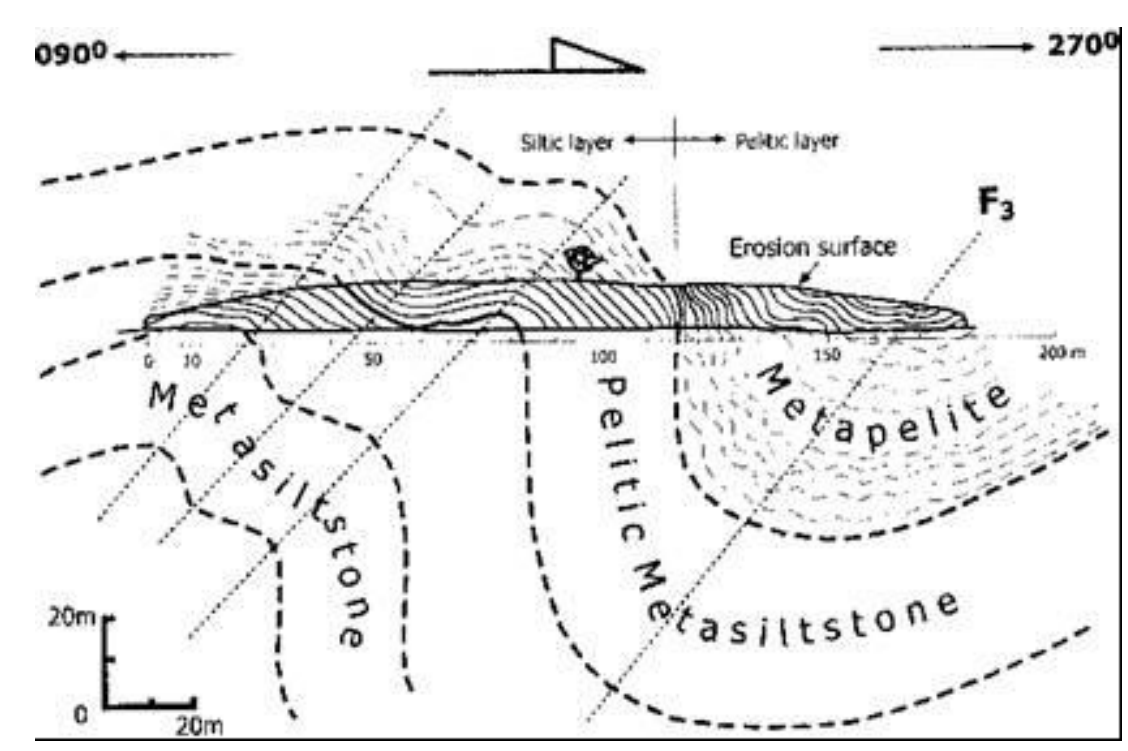

Fig. 9. Sketch of a hm-scale, W-verging $F_{3}$ fold observed in outcrop 7, NW of the dome, in the paved road to Morrinhos (Fig. 4). The limits of the road cut are drawn in the center of the figure. A succession of layers of metasiltstone, pelitic metasiltstone, and metapelite define the primary layering $\left(\mathrm{S}_{0}\right)$ that is affected by a layer-parallel foliation $\mathrm{Si}$ commonly marked by fine-grained white mica (biotite also occurs in the lowermost layer to the left), all affected by the $S_{2}$ foliation (mostly fine-grained white mica). The $L_{2-1}$ intersection lineation is down-dip along the planes of $S_{1} / S_{0}$ and subparallel to the axis of several $10 \mathrm{~cm}$-scale $F_{2}$ folds. Such planar and linear structures change dip or plunge either $E$ or $W$ along the respective limbs of the major folds, demonstrating that the larger structure is an $F_{3}$ fold. Fractures and quartz veins (omitted for simplicity) also occur but are less important. The entire structure indicates a top-to-W shear and, as in the fold in Fig. 8, fits the interpretation for a gravity slide during the Caldas Novas dome's uplift. The metapelite layer is more intensively folded to accommodate more intense shortening in the core of the major synform.

\subsection{Brittle deformation: fractures and quartz veins}

Fractures/joints and quartz veins that occur throughout the area and cross-cut $D_{1}-D_{3}$ structures in all rock types have been labelled $S_{4}$ (Fig. $6 f$ and $g$ ) and interpreted as the record of a late event of brittle deformation $\left(D_{4}\right)$. They are commonly sharp and well defined in outcrops of the Paranoa rocks but are more rare in outcrops of the Araxa rocks. The fractures are generally subvertical and statistically distributed in five main sets, $v$ to $w$. Fractures $v$ (the largest) and fractures $z \sim y$ (the second largest) strike WNW and NNE, respectively, corresponding to directions subparallel and subperpendicular to the direction of $L_{x}$. Fractures $x$ and $w$ strike along intermediary directions between these two extremes and are nearly perpendicular to each other. Data in Fig. $6 \mathrm{~g}$ define three main populations of quartz veins: $\mathrm{Va}, \mathrm{Vb}$, and $\mathrm{Vc}$. The $\mathrm{Va}$ veins, which are subperpendicular to $L_{x}$, are generally thicker than Vbs, which are subparallel to the direction of $L_{x}$, and both are found everywhere. Veins $V_{c}$ are parallel to the main population of $\mathrm{S}_{3}$ and $\mathrm{AP}_{3}$ (Fig. 6d) and more common in Paranoa quartzites of the eastern limb of the dome (outcrops 70 and 71, Fig. 6a). Only 
two such veins were found in outcrops 47 and 49 of Araxa, close to the SE and SW borders of the dome, respectively. The vein in outcrop 49 is as thick as $\mathrm{Va}$ veins $($ maximum thickness $=25 \mathrm{~cm}$ ).

\section{Tectonic evolution of the Caldas Novas dome}

\subsection{Structural evolution}

The fact that $S_{1}, S_{0}$, and $S_{2}$ are subparallel, the ESE vergence of $F_{2}$ folds and their isoclinal style, the asymmetry of $S-C\left(=S_{1}\right)$, and the down-dip stretching lineation all indicate a $D_{1}-D_{2}$ progressive event of intra- and interlayer slip that corresponds to a regional rotational deformation (assumed as simple shear) along surfaces dipping at low angle to the WNW - in other words, a typical regime of frontal ramps. Therefore, $D_{1}-D_{2}$ maximum compression $\left(S_{1}\right)$ in the area was subhorizontal and took place along the same direction of the mean stretching vector $\left(296^{\circ}\right)$. Nevertheless, though $D_{3}$ records a progressive shortening of the area, the attitude of $D_{3}$ structures implies that the shortening direction shifted to WSW-ENE.

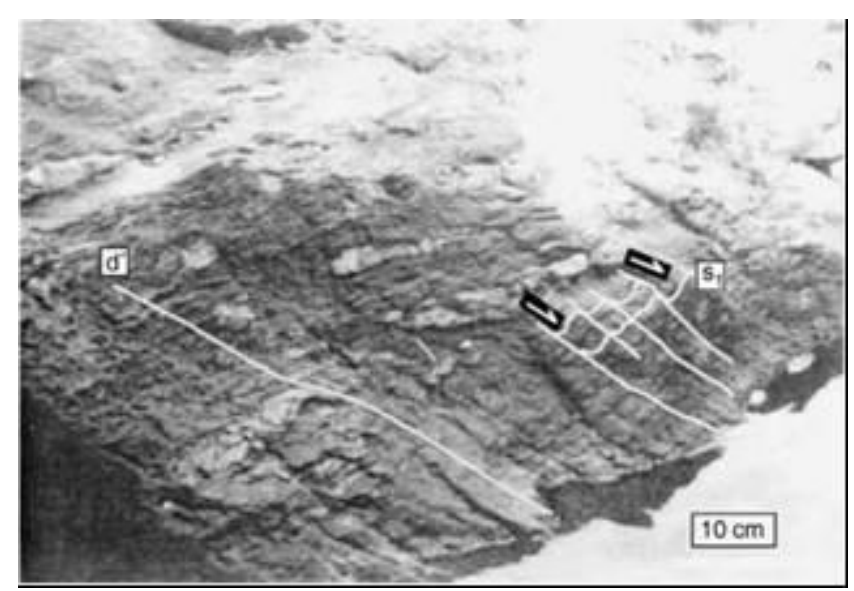

Fig. 10. Photograph taken in outcrop 2 (NE of the dome) to show the $d^{0}=053748^{\circ}$ extensional crenulation cleavage affecting planes of $S_{1}=340712^{\circ}$ in the Araxa schist and implying a top-down to ENE slip. The outcrop is along a creek, a few meters away from the paved road.

The interpretation of WSW-ENE shortening during $D_{3}$ is strongly supported because the direction of $L_{x}\left(D_{1}-D_{2}\right.$ stretching lineation) is the same on the western and eastern sides of the Caldas Novas dome. If, for example, 
the dome was formed initially as a consequence of WNW-ESE regional ductile flow and underwent rotation to its present NNW-SSE position (whether due to different intensities of the flow itself or the slip along WNW-ESE-striking lateral ramps north of the dome, as in Fig. 3), these processes would also affect $L_{x}$ and the trace of $S_{0 / 1}$ and $S_{2}$, so the dome would appear as a rotated porphyroblast-like structure in regional maps (similar to the Itabaiana dome in the Sergipano belt, NE Brazil; D'el-Rey Silva, 1992; 1995a,b; D'el-Rey Silva and McClay, 1995). The complete lack of evidence of such rotation indicates that the final position of the Caldas Novas dome is the same as that in which it was formed.

Relative to $D_{4}$, it is notable that veins $V c$ display orientation and distribution compatible with the uplift of the dome. However, fracture planes labelled $v$ are usually open, subvertical, strike parallel to the subhorizontal regional compression $\left(S_{1}\right)$, dip parallel to the subvertical internal compression $\left(S_{1 i}\right)$, and host veins $(\mathrm{Vb})$ that are subparallel to $L_{x}$. In addition, Va veins are hosted along fractures that are subperpendicular to $L_{x}$ and, by playing the role of $T$ fractures, are expected to develop in the same shearing regime. As shown in Fig. $6 \mathrm{~g}$, Va veins are concentrated in two populations of planes with similar strike but different dips (subvertically or steeply) to the ESE, which may be the result of the progressive emplacement and rotation of veins along $T$ fractures. Finally, the parallel relationship between $\mathrm{Vc}$ veins and $\mathrm{S}_{3} / / \mathrm{AP}_{3}$ match the direction of extension expected for the limbs of the dome during gravity-induced slides.

\subsection{The Caldas Novas dome as a $D_{3}$ structure}

On the basis of the unequivocal evidence found in the Paredao outcrop, it can be safely stated that the Caldas Novas dome formed during a $D_{3}$ deformation. The outcrop is continuous along a $3 \mathrm{~m}$ wide stream that flows down to the east in a cascade created by the rounded hinges of east-verging, steeply inclined, $<5 \mathrm{~m}$ scale $F_{3}$ asymmetric antiforms (Fig. 11a-d). These hinges affect Paranoa quartzite layers that display the $S_{1} / / S_{0}$ foliation, as well as several $\sim 1 \mathrm{~m}$ scale $F_{2}$ isoclinal folds that refold around the $F_{3}$ hinges (Fig. 
11e). The isoclinal style of the $F_{2}$ folds and the maintenance of their original vergence to the ESE demonstrate that the dome is a major $F_{3}$ antiform, not a large $F_{2}$ fold. Moreover, the vergence of the $<5 \mathrm{~m}$ scale $F_{3}$ folds supports their interpretation as gravity sliding structures related to the dome's uprise. If they were parasitic folds in the E-dipping limb of a major antiform, they would verge to the west.

Because of the gravity slide, foliation $\mathrm{d}^{0}$ developed to extend the matter, whereas several $F_{3}$ folds developed to shorten it during the way down. The $F_{3}$ folds on the western side of the dome verge west; some may attain a scale of $300 \mathrm{~m}$ or more (Fig. 9), whereas others may imply the development of a collapse breccia (Fig. 8). The $F_{3}$ folds within the Araxa schists of the eastern border of the dome are hm scale but verge east, and their eastern limbs (closer to the dome) are associated with small-scale intense crenulation that may compensate for the amount of extension implied by $d^{0}$ foliation, which is very intense in outcrops of Araxa schists in the same area (e.g. outcrops 47, 41, 75; Fig. 6a).

The uplift of the dome modified the attitude of the $D_{1}-D_{2}$ anisotropy $\left(\mathrm{S}_{0} / / \mathrm{S}_{1} / / \mathrm{S}_{2}\right)$ in such a way that the original dip, mostly to the NW, turned in all directions. However, despite this obvious effect, the strike of the stretching lineation was maintained across the area (Fig. 4a), and the plunge of $L_{x}$ changed from $296^{\circ}$ to the opposite direction ( $116^{\circ}$; Fig. 4d) with no significant variations to the $S$ or $N$. A similar situation is observed for $L_{2}$ and $L_{\text {s-c. }}$ In some outcrops along the western and eastern margins of the dome, the lines are down-dip and parallel to the regional $L_{x}$ (e.g. 09, 17, and 40 to the $W ; 45$ and 66 to the $\mathrm{E})$. Together, these data indicate that the direction of stretching is coincident with the horizontal axis of rotation of the layers during uplift of the dome. Moreover, in outcrops along the northern $(57,59,60)$ and southern (12; Fig. 4a) margins of the dome, $L_{2}$ and $L_{s-c}$ are parallel to $L_{x}$ but display much lower rake and even become parallel to the strike of $S_{0} / / S_{1} / / S_{2}$. This situation is expected due to the tilt of $S_{0} / / S_{1} / / S_{2}$ planes and may be attained even with a small modification of their angle of dip. 


\subsection{Is the Caldas Novas dome a $D_{3}$ structure?}

Together with the $F_{3}$ folds and foliation $S_{3}$, plus the similar conditions of ductility for $d^{0}$ and $c^{0}$ (which reflects great $D_{2}-D_{3}$ metamorphic compatibility), the heterogeneous distribution of $d^{0}$ in the area demonstrates that the dome is a $D_{3}$ structure formed in a progressive event following $D_{2}$. The fact that $d^{0}$ is characteristically absent on the western side of the dome works strongly against other possible interpretations.

Foliation $d^{0}$ might be interpreted as a $D_{2}$ structure that affected $c^{0}$ planes during progressive deformation. However, if this was the case, $d^{0}$ would be found everywhere in the area, and the uplift of the dome would affect $d^{0}$ in all of its quadrants (as happened with $\mathrm{c}^{0}$ ). The dome also might be interpreted as a much younger structure (e.g. Cretaceous) due to a magma intrusion. In this case, the lack of a reasonable argument for $d^{0}$ as a syn- $D_{2}$ structure would lead to the interpretation that $d^{0}$ is a Cretaceous structure. Again, there is no reason for $d^{0}$ be absent along the west side of the dome; in addition, the similar conditions of ductility for $\mathrm{c}^{0}$ and $\mathrm{d}^{0}$ would require a warming up of the dome area in the Cretaceous. An igneous intrusion beneath the site of the dome could provide heat for such event, but it remains hard to accept that the Araxa rocks could be heated more intensively than the Paranoa rocks that lie closer to the hypothetical intrusion. Even accepting this, we also would have to accept that heat propagated heterogeneously upward and did not affect the Araxa rocks west of the dome. In addition to this negative coincidence, two other points work against the idea that the dome is due to a younger igneous intrusion: (1) Why would such a dome have to be elliptical? (2) Why would its longer axis have to trend exactly NNW, not in any other position? The elliptical shape and the trend of the Caldas Novas dome's longer axis both support $D_{3}$ evolution in the Brasiliano cycle and fit within the characteristics of $\mathrm{D}_{3}$ regional event existing in the southern segment of the Brasilia fold belt. The last possibility against the Brasiliano cycle $D_{3}$ evolution of the dome is even harder to accept, in that it considers $d^{0}$ as a Brasiliano $D_{2}$ structure and the uplift of the dome as due to a Cretaceous intrusion. If this happened, during event $D_{2}$ foliation $\mathrm{d}^{0}$ did not form in a particular area, and the younger intrusion took 
place exactly at a point capable to make the area coincident with the west side of the dome.
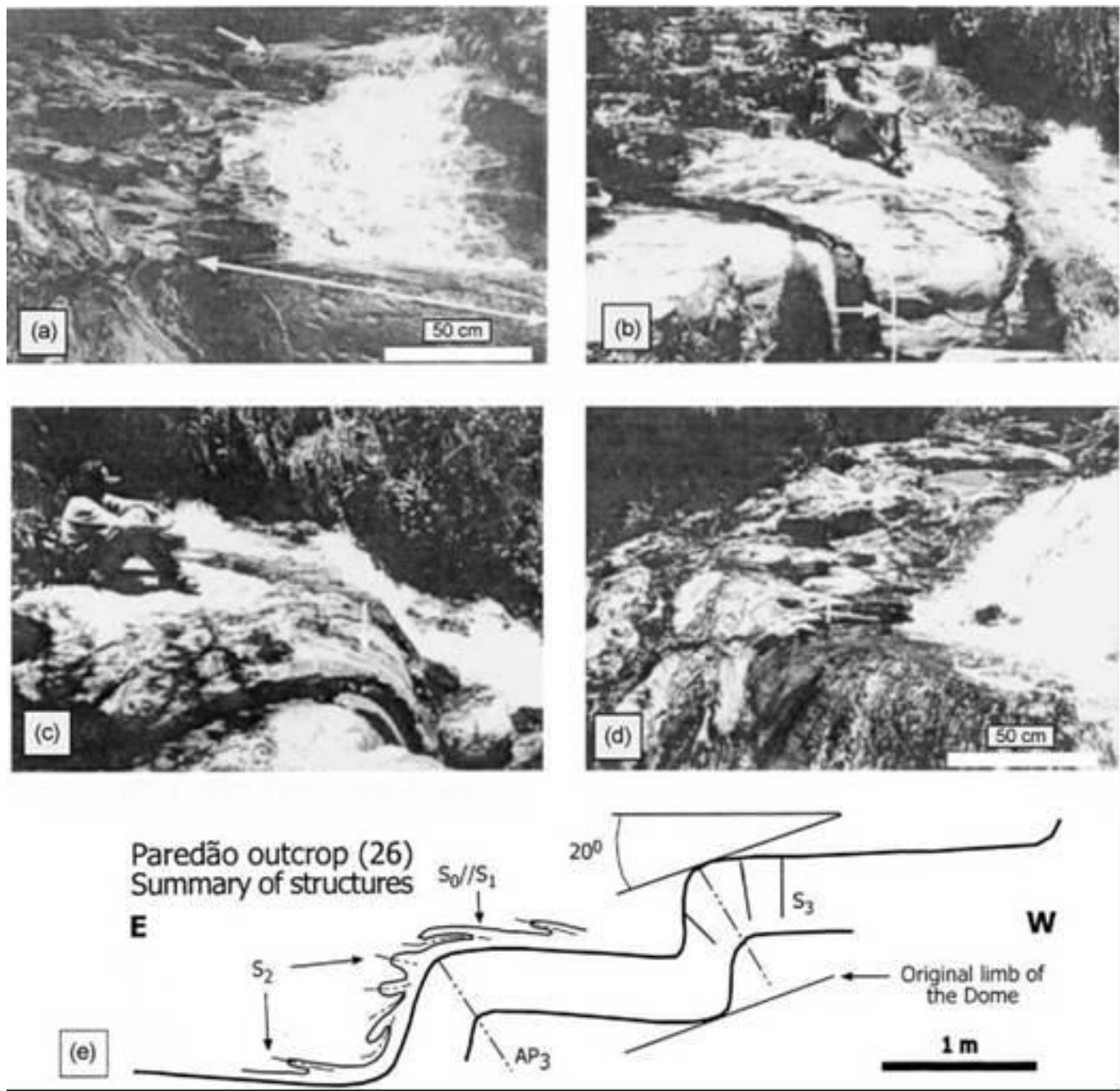

Fig. 11. The Paredao outcrop. (a) Cascade created by the hinge of $m$-scale $F_{3}$ folds. The white line marks the hinge of a major antiform in the foreground, and the arrow in the background points to a white tape laid down in the field around another $F_{3}$ hinge. Three other $F_{3}$ antiforms occur in between. The scale applies to the foreground. The hinge of the antiform (marked by the white tape) is seen in more detail in (b) and (c). (d) A closer view of the hinge of the main antiform. The $F_{2}$ folds systematically bend around the $F_{3}$ folds as depicted in (e). The envelope surface for the $F_{3}$ folds provides the original dip of the dome's eastern limb (around $20^{\circ}$ ).

The absence of $d^{0}$ in the western limb of the dome can be explained because during $D_{3}$, that limb remained in a position similar to that it had during $\mathrm{D}_{2}$, as well as under compression due to the progressive regional ductile flow that counterbalanced the gravity effect and made it difficult for $d^{0}$ to develop there. Simultaneously, as the eastern limb rotated from a dip-to-WNW to a dipto-E, it entered a zone more protected from the regional flow, so the gravity effect could act freely. Therefore, $d^{0}$ is abundant there. The extension to the $\mathrm{N}$ 
and $S$ implied by $\mathrm{d}^{0}$ fits in and reinforces this interpretation. The isolated occurrence of foliation $\mathrm{d}^{0}$ in outcrop 10 (NW of the dome, Fig. 6a), which implies it extended to the $S$, may be attributed to the growth of the rolling hinge of the large $F_{3}$ folds seen in outcrop 7 (Fig. 9) located to the $\mathrm{N}$. If this possibility is proven, it lends additional support to the interpretation that the gravity-induced folds are $D_{3}$ structures.

\subsection{A model for $D_{3}$ evolution and underground thermal waters}

Any model about the evolution of the Caldas Novas dome should take into account the possibility that the Paranoa quartzite actually extends down nearly $1000 \mathrm{~m}$ and should provide an explanation for this abnormal thickness. The $1000 \mathrm{~m}$ of quartzites could be due to deposition of voluminous siliciclastics in a particularly deeper depocenter, the site of the future Caldas Novas dome, as is the case for the Itabaiana gneiss dome of the Sergipano belt, where the basal quartzite formation is less than $50 \mathrm{~m}$ thick regionally but attains a thickness of $700 \mathrm{~m}$ around the dome as a consequence of a kind of half-graben associated with the hanging wall of a system of extensional listric faults (D'elRey Silva, 1992, 1995a; D'el-Rey Silva and McClay, 1995). The evolution of such a fault system led to the initial uprise of the dome during the sedimentation and volcanism of the precursor basin, and the incipient Itabaiana dome thus received a crown of carbonates covering the quartzites.

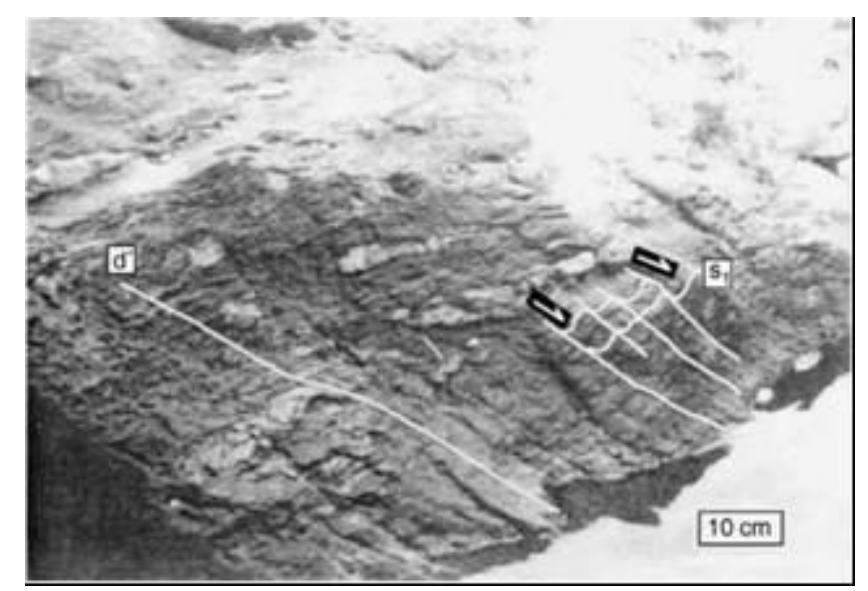

Fig. 12. Photograph taken in outcrop 2 (NE of the dome) to show the $d^{0}=053748^{\circ}$ extensional crenulation cleavage affecting planes of $S_{1}=340712^{\circ}$ in the Araxa schist and implying a top-down to ENE slip. The outcrop is along a creek, a few meters away from the paved road. 
In contrast, the Caldas Novas dome area displays no lithostratigraphic information that might detail the possible tectonic evolution of the sedimentation in that part of the Brasilia belt; therefore, sedimentary control over the abnormal thickness cannot be demonstrated or ruled out. Nevertheless, a tectonic explanation for the abnormal thickness may be easily envisaged with the aid of out-of-sequence thrusts (Butler, 1987; McClay, 1992) and a $D_{3}$ duplex structure or antiformal stack (Boyer and Elliott, 1982) hidden in the core of the $F_{3}$ fold that corresponds to the dome (Fig. 12). However, because the study area lacks even a simple control over the regional thickness of the Paranoa group, this model is just one of several plausible ideas that vary according to the regional thickness.

The structural model for the Caldas Novas dome (Fig. 12c) agrees with the physical parameters required for the $50{ }^{\circ} \mathrm{C}$ hot springs, such as those shown near Pousada park (Fig. 6). A model for the evolution of the underground reservoir considers that meteoric waters would infiltrate regionally into the Paranoa group and percolate until they reached the bottom of the quartzite layers in the core of the dome, where they would attain the highest temperatures and then migrate quickly upward through a net of brittle structures that could combine planes of $S_{3}$ spaced cleavage and $D_{4}$ fractures. The model accounts for the nature and inventory of the $D_{3}$ and $D_{4}$ structures mapped at surface but cannot attain a higher degree of complexity until a very detailed geophysical survey combining, for example, seismic reflection, induced polarization, and hydrologic modelling provides additional information. Researchers working recently in Caldas Novas (e.g. Troger et al., 1999; Campos et al., 2000; Zschocke, 2000) agree that the uprise of thermal waters through different geological units in a complex hydraulic manner, controlled by the structural features observed in the area, leads to reservoirs with different chemical characteristics and temperatures.

It is possible that a younger magmatic rock (e.g. Cretaceous) was placed in the core of the $D_{3}$ dome (Fig. 12c), which enhanced the mechanical porosity by reopening at least part of the Brasiliano cycle $D_{3}-D_{4}$ brittle structures and facilitating the underground flow of waters. This hypothetical intrusion also 
could be the source of at least part of the heat required to warm up the waters. Again, only a very detailed geophysical study could provide reliable information about whether such an intrusion exists or not. The results of recent geochemical and isotope studies (Zschocke, 2000; U. Trogger, pers. comm.) indicate no contribution from a magmatic intrusion for the composition of thermal waters in the Caldas Novas area.

\section{Implications for understanding the Brasilia belt and Tocantins province}

The structural and tectonic analyses of the Caldas Novas area suggest the following:

1. The $D_{1}-D_{3}\left(D_{4}\right)$ evolution described may be bracketed in the 750-600 Ma interval, according to the age of syntectonic granitic intrusions located to the NW and E of Ipameri, as well as of granulite facies metamorphism near the study area;

2. The $D_{1}-D_{2}$ tectonics of frontal ramps with $S_{1}$ oriented to the WNW-ESE in the Caldas Novas area is the same that has been demonstrated in Ipameri, as well as in other parts of both the southern and northern segments of the belt along the magmatic arc-continental plate margin or closer to the Sao Francisco craton (Fig. 1b; D'el-Rey Silva and Barros Neto, 2002). Thus, despite the bend of the Brasilia belt, there is a strong coincidence in the WNW-ESE direction of the regional stretching lineation and maximum horizontal compression $\left(S_{1}\right)$ for $D_{1}-D_{2}$ in both the northern and southern segments of the belt;

The Caldas Novas dome is a $D_{3}$ antiformal structure, implying a WSWENE-trending shortening, remarkably coincident with the direction of shortening in the $F_{3}$ folds that affect the $D_{1}-D_{2}$ Araxa, Passos and Luminarias nappes in the southern segment of the belt (Fig. 2; Seer, 1999; Seer et al., 1999; Seer and Dardenne, 2000; Valeriano et al., 2000);

3. Such a $D_{3}$ event is regionally absent in the northern segment of 
the belt. The single well-documented example of WSW-ENE $D_{3}$ shortening in the northern segment of the belt is a local phenomena and related to the escape of the rocks to the SSE during formation of $D_{2}$ sheath folds that control emerald ore shoots in the mining district of Campos Verdes in the MA (Fig. 1b; Barros Neto, 2000; D'el-Rey Silva and Barros Neto, 2002; D'el-Rey Silva, 2002b);

4. The age of $D_{3}$ deformation in the southern segment of the belt must be close to 600 Ma (Pimentel et al., 1999 for the Ipameri area; Seer, 1999; Valeriano et al., 2000 for the southernmost part of the belt; Seer (1999) for the structural analysis), which fits the age of opening of the rift-like basin precursor of the Paraguay belt (Alvarenga and Trompette, 1992; Pimentel et al., 1996; Alvarenga et al., 2000); and

5. The direction of $D_{3}$ shortening fits with the movement of the Socorro-Guaxupe nappe that evolved in the 620-510 Ma interval and displaced high- $P$ basement rocks onto the $F_{3}$ regional folds that affect the Araxa, Passos and Luminárias nappes (Fig. 2; Valeriano et al., 2000).

We have avoided correlating the WSW-ENE direction of shortening $\left(D_{3}\right)$ with a particular stress field because the likelihood that the NNW-SSE trend of the Caldas Novas dome (the $\mathrm{F}_{3}$ antiform) records the same position in which it formed originally does not suggest a straightforward similarity between the direction of shortening and the direction of maximum compressive stress. In addition, the Caldas Novas dome $\mathrm{F}_{3}$ antiform did not form in the same NE-SW trend of the nonrotated $F_{2}$ folds in the study area, which does not authorize a denial that the WSW-ENE $D_{3}$ shortening could be due to the same WNW-ESE subhorizontal stress field (sj) active since the $\mathrm{Dj}-\mathrm{D}_{2}$ events. However, to correlate the WSW-ENE shortening with the WNW-ESE-trending $S_{1}$, the three following hypotheses should be considered: (1) $D_{3}$ shortening is due to different velocities of the WNW-ESE flow along the planes of $S_{0} / S i / S_{2}$, (2) $D_{3}$ shortening was due to $S_{2}$, and (3) The rocks in the study area (and in the Araxa, Passos, and Luminarias nappes) underwent $D_{3}$ shortening due to WNW-ESE flow that took place in the basement. 
Hypothesis 1 seems quite unlikely because the basement crops out as a dorsal between the $F_{3}$ synforms that affect the Passos and Luminarias $D_{1}-D_{2}$ nappes (Fig. 2), which indicates that nappe emplacement involved the crystalline basement of the Sao Francisco craton, at least south of the Caldas Novas dome, and the whole vertical column of the $D J-D_{2}$ nappes underwent $D_{3}$ shortening. If not involved in the nappes, then the basement marks the hinge of an intervening antiform between two $F_{3}$ synforms, or it crops out because of erosion. The first case requires a $D_{3}$ detachment within the basement, which is most reasonable because $D_{3}$ is a regional event. In the second case, the $D_{3}$ detachment lies along the basement-cover interface, and it would have had to jump exactly the narrow site of the basement between two $F_{3}$ synforms. Hypothesis 2 also is hard to accept because $S_{2}$ alone would have to shorten a thicker pile of rocks after $D_{1}-D_{2}$. Folds due to $S_{2}$ must form simultaneously with folds due to $S_{1}$, not afterwards. Hypothesis 3 implies that the $D_{1}-D_{2}$ regional flow continued solely in the basement during $D_{3}$, without a detachment between two crustal levels. In addition, the WNW -ESE flow in the crystalline basement would have to be contemporaneous with $D_{3}$ in the upper level. To date, ductile flow in the basement during $D_{1}-D_{2}$ does not indicate that the basement was part of the $D_{1}-D_{2}$ nappes. Furthermore, if Hypotheses 1-3 are true, why is a regional WSW-ENE $D_{3}$ shortening regionally absent in the northern segment of the belt?

Therefore, most likely $D_{3}$ event involved the basement, and the maximum compression responsible for the $D_{3}$ structures was not the same as that responsible for $D_{1}-D_{2}$ events. It sounds interesting to interpret another maximum compression (e.g. $\sigma_{1}{ }_{3}$ ) as parallel to the direction of $D_{3}$ shortening. Nevertheless, despite its existence, the younger field $\sigma_{{ }_{1}{ }_{3}}$ does not require that the older one became inactive in the late stage of the evolution of the southern part of the belt. If so, which tectonic scenario could account for coexisting stress fields, and why should the effects of the WSW-ENE field overcome the effects of the WNW-ESE one? Instead of competing with $S_{1}$, the younger maximum compression $\sigma_{1}{ }_{3}$ may have added to the effect of $S_{2}$ during $D_{3}$ and facilitated the WSW-ENE shortening. Of great relevance is that the southern segment of the Brasilia belt displays clear evidence for a regional event of WSW-ENE shortening that affected both basement and cover and was active for 
approximately $100 \mathrm{Ma}$, progressively overprinting $D_{1}-D_{2}$ structures that formed across the belt as a consequence of a WNW-ESE-driven tectonic transport during 750-600 Ma. These two distinct events, their characteristics, and the preceding questions all demand a comprehensive tectonic analysis of the Tocantins Province that is beyond the scope of this paper.

\section{Conclusions}

The Caldas Novas dome is an elliptic structural window with a $\sim 20 \mathrm{~km}$ long maximum axis trending NNW, cored by subgreenschist facies rocks of the Meso-Neoproterozoic Paranoa group and mantled by a nappe of greenschist facies (biotite zone) rocks of the Neoproterozoic Araxa group. These rocks underwent three $\left(D_{1}-D_{3}\right)$ events of mainly ductile progressive deformation in the ca.750-600 Ma interval and indicate typical tectonics of frontal ramps. A set of brittle fractures and veins characterizes the youngest event recorded in the area. Both $D_{1}$ and $D_{2}$ record an event of regional simple shear along surfaces that dip gently to the NW, with a top-to-SE relative displacement and a maximum subhorizontal compression $\left(S_{1}\right)$ oriented $290-300 \% 1110-120^{\circ}$. The Araxa rocks experienced more severe metamorphism than did the Paranoa rocks during $D_{1}$ and were emplaced as a nappe during $D_{2}$. Event $D_{3}$ implies additional shortening and records a WSW-ENE-driven compression, during which the dome started to rise as a large- scale $F_{3}$ fold, possibly associated with a duplex structure at depth. Continuous with the uplift of the dome, the layers slid down, giving way to gravity-slide $D_{3}$ structures, such as extensional crenulation cleavage, folds, and tectonic breccia heterogeneously distributed across the area. The underground reservoir likely is fed by meteoric waters that percolate through the Paranoa group, attain temperatures of more than $50^{\circ} \mathrm{C}$ at a depth of $1000 \mathrm{~m}$, and travel quickly upward through a mechanical porosity consisting of a net of $D_{3}$ and $D_{4}$ planar brittle structures. Detailed geophysical work could provide additional information. The $D_{1}-D_{2}$ structural and tectonic evolution of the Caldas Novas dome area is similar to several other areas of the whole Brasilia belt and took place in the $~ 750-620 \mathrm{Ma}$ interval. Moreover, the dome itself demonstrates the importance of the 620-510 Ma old $D_{3}$ event of 
WSW-ENE shortening that is evident across the southern segment of the Brasilia belt and virtually absent in the northern one.

\section{Acknowledgements}

Luiz D'el-Rey Silva acknowledges CNPq-Brazil for scholarship and research funds (1987-2001) and CAPES-Brazil for postdoctoral research Grant BEX-1922/99-8 throughout 2001. He also thanks Prof. K.R. McClay's Fault Dynamics Group (Geology Department, RHUL) and the Geological Survey of Finland (in particular Prof. Gabor Gaal, Research Director) for support during his stay in Egham, UK, and Helsinki, respectively. Two anonymous referees for the Journal of South American Earth Sciences are thanked for their valuable comments on previous versions. Detlef G. Walde and Percy B.W. Klein both thank UnB-IG, and Percy thanks UFG-Campus Catalao for support received during their careers. The authors thank geologists Fabio F. Haesbeart and Fernando Gabier for important information and assistance in Caldas Novas. This paper is part of Project FAPESP 96/1566-0, coordinated by Prof. A.J. Berrocal Gomes (USP-Sao Paulo).

\section{References}

Alvarenga, C.J.S., de Trompette, R., 1992. Glacially-influenced sedimentation in the Later Proterozoic of the Paraguay Belt (Mato Grosso, Brazil). Palaeogeography, Palaeoclimatology, Palaeoecology 92, 85-105.

Alvarenga, C.J.D.de, Moura, C.A.V., Gorayeb, P.S.de.S., Abreu, F.A.M.de, 2000. Paraguay and Araguaia belts. In: Cordani, U.G., Milani, E.J., Thomaz Filho, A., Campos, D.A. (Eds.), Tectonic Evolution of South America. 31 International Geological Congress, Rio, pp. 183-193.

Barros Neto, L.de S., 2000. Evolução Estrutural do Distrito Esmeraldifero de Campos Verdes, GO. MSc Dissertation 149. Universidade de Brasilia, Enclosure with a $1: 25,000$ scale map and cross sections $111 \mathrm{pp}$.

Boyer, S.E., Elliott, D., 1982. Thrust systems. American Association of Petroleum Geologists Bulletin 66(9), 1196-1230.

Brod, J.A., Leonardos, O.H., Menezes, P.R., Albuquerque, M.A.C., Almeida, R., Araujo, R.N.G., Blanco, S.B., Cardoso, F.B.F., Carvalho, O.A. Jr., Junqueira, F.F., Riedl, W. Jr., Romao, P.A., Souza, J.C.F., Tallarico, F.H.B., Thomsen, F.P.R., Berbert, M.L.C., Cerqueira, M.R.S., Chagas, M.A., Dias, R.R., Lima, C.V., 
Nakamura, E.T., Porto, S.G., Santos, P.C.V., 1991. Tectonoestratigrafia da Faixa Brasilia na regiao do Alto Paranaiba. Simpósio de Geologia do Centro-Oeste 3, 155-168.

Butler, R., 1987. Thrust sequences. Journal of the Geological Society 144, 619-634.

Campos J.E.G., Fortes P.F., Santos R.V., 2000, Geologia do Domo de Caldas Novas. Internal report, UnB-IG, 80 pp.

Drake, A.A., Jr., 1980. The Serra de Caldas window, Goiais. Tectonic Studies in the Brazilian Shield. Geological Survey of America Professional Paper 1119-A, 13 pp.

D'el-Rey Silva, L.J.H., 1992. Tectonic evolution of the southern part of the Sergipano fold belt, northeastern Brazil. PhD Thesis. Royal Holloway, London University, 258 pp.

D'el-Rey Silva, L.J.H., 1995a. The evolution of basement gneiss domes of the Sergipano fold belt (NE Brazil) and its importance for the analysis of Proterozoic basins. Journal of South American Earth Sciences 8(3/4), 325-340.

D'el-Rey Silva, L.J.H., 1995b. Tectonic evolution of the Sergipano belt, northeastern Brazil. Revista Brasileira de Geociencias 25(4), 315-332.

D'el-Rey Silva, L.J.H., 2002a. The belt of Neoproterozoic granulites in the inner part of the Brasilia belt: Implications for collision tectonics and exhumation processes. XLI Congresso Brasileiro de Geologia, Joao Pessoa. Anais SBG, 341.

D'el-Rey Silva, L.J.H., 2002b. The Caldas Novas and Santa Cruz domes: Structural evolution and implication for tectonics in the Brasilia belt, central Brazil. XLI Congresso Brasileiro de Geologia, Joao Pessoa. Anais SBG, 341.

D'el-Rey Silva, L.J.H., Barros Neto, L.de.S., 2002. The Santa Terezinha- Campos Verdes emerald district, central Brazil: Structural and Sm-Nd data to constrain the tectonic evolution of the Neoproterozoic Brasilia Belt. Journal of South American Earth Sciences 15(6), 697 -708.

D'el-Rey Silva, L.J.H., McClay, K.R., 1995. Stratigraphy of the southern part of the Sergipano belt, NE Brazil: Tectonic implications. Revista Brasileira de Geociencias 25(3), 185-202.

D'el-Rey Silva, L.J.H., Fuck, R.A., Ferreira Filho, C.F., Nilson, A.A., 1996, The Niquelandia layered intrusion and underthrutsting in the Brasilia fold belt. XXXIX Congresso Brasileiro de Geologia, Salvador, Anais SBG 6, Simpoisios, pp. 87-91.

D'el-Rey Silva, L.J.H., Ferreira Filho, C.F., Nilson, A.A., Oliveira, A.C. de, Silva Jr., C.G., Silva, C.B., Medeiros, E.S., Campos, G.S., Cruz, H.P., Zoby, J.L.G., Almeida, J.C.M., Pinelli, M.P., Mongim, R.M., Algarte, R.D., Bispo, R.S., Souza, R.S., Silva, V.V., 1997. Uplift of the Barro Alto mafic-ultramafic intrusion by underthrusting in the northern segment of the Brasilia belt, Brazil. VI Simpoisio Nacional de Estudos Tectonicos, Pirenopolis-Go, Anais SBG, pp. 53-56.

Fischel, D.P., 2002, Geologia isotopica U-Pb e Sm-Nd da Seqüencia Silvania, Complexo Anapolis-Itaucu e Grupo Araxa na regiao de Leopoldo de Bulhões, Goias: Contribuicao ao estudo da evoluçao da Faixa Brasilia. PhD Thesis 55. Universidade de Brasilia, 162 pp. 
Fischel, D.P., Pimentel, M.M., Fuck, R.A., 1998. Idade do metamor- fismo de alto grau no Complexo Anaipolis-Itaucçu. Goiais, determinada pelo metodo Sm-Nd. Revista Brasileira de Geociencias 28(4), 543-544.

Fischel, D.P., Pimentel, M.M., Fuck, R.A., 1999a. Preliminary Sm-Nd isotopic study of the Araxa Group, central Goias. VII Simposio de Geologia do Centro-Oeste e X Simpoisio de Geologia de Minas Gerais, Brasilia, Boletim de Resumos, SBGDF/MG/CO, 87pp.

Fischel, D.P., Fuck, R.A., Pimentel, M.M., 1999b. Sm-Nd mineral isochrons and model ages of the Anaipolis-Itaucçu complex and associated granites, Goias: New insights into the geological evolution of the Brasilia Belt. VII Simpoisio de Geologia do Centro-Oeste e X Simpoisio de Geologia de Minas Gerais, Brasilia, Boletim de Resumos, SBG-DF/MG/CO, p. 88.

Fischel, D.P., Pimentel, M.M., Fuck, R.A., 1999c. Dados Sm-Nd Preliminares dos Anfibolitos entre Silvania e Bonfinopolis. Goias. VII Simposio de Geologia do Centro-Oeste e X Simposio de Geologia de Minas Gerais, Brasilia, Boletim de Resumos, SBG-DF/MG/CO, p. 89.

Fuck, R.A., Jardim de Sa, E.F., Pimentel, M.M., Dardenne, M.A., Pedrosa- Soares, A.C., 1993. In: Domingues, J.M.L., Misi, A. (Eds.), As faixas de dobramentos marginais do Craton do Sao Francisco: Sintese dos conhecimentos. O Craton do Sao Francisco, SBG/SGM/CNPq, pp. $161-185$

Fuck, R.A., Pimentel, M.M., D’el-Rey Silva, L.J.H., 1994. Compartimen- tacao Tectonica na Porçao Oriental da Província Tocantins. XXXVIII Congresso Brasileiro de Geologia, Camboriui, SBG. Boletim Resumos Expandidos 1, 215 217.

Haraly, N.L.E., 1978. Carta gravimetrica Bouguer do oeste e sul de Minas Gerais, nordeste de Sao Paulo e do sul de Goias. PhD Thesis. University of Sao Paulo (USP), $288 \mathrm{pp}$.

Haraly, N.L.E., 1980. Carta gravimeitrica do Oeste de Minas Gerais, Sudeste de Goias e Norte de Sao Paulo. XXXI Congresso Brasileiro de Geologia, Camboriui, Anais SBG, 2639-2643.

Lacerda Filho, J.W., Rezende, A., da Silva, A., 1999. Programa de Levantamentos Geoloigicos Baisicos do Brasil. Geologia e Recursos Minerais do Estado de Goias e Distrito Federal, Escala 1:500.000, CPRM Goiania.

Lister, Snoke, 1984. S-C mylonites. Journal of Structural Geology 6, 617-638.

Marini, O.J., Fuck, R.A., Dardenne, M.A., Danni, J.C.M., 1984, Provincia Tocantins, Setores Central e Sudeste. In: Almeida de, F.F.M., Hasui, Y, (Coord.), O Precambriano do Brasil, (Ed. Edgard Blucher), pp. 205-264.

McClay, K.R., 1992. Glossary of thrust tectonics terms. In: McClay, K.R., (Ed.), Thrust Tectonics. Chapman \& Hall, xxx, pp. 409-433.

Oriente, T., 1982. In: Oriente, T., (Ed.), As fabulosas aguas quentes de Caldas Novas, pp. 147, Goiania.

Pimentel, M.M., Fuck, R.A., 1992. Neoproterozoic crustal accretion in central Brazil. Geology 20, 375-379. 
Pimentel, M.M., Fuck, R.A., Alvarenga, C.J.S., 1996. Post-Brasiliano (Pan-African) high-K granitic magmatism in central Brazil: the role of Late Precambrian-Early Paleozoic extension. Precambrian Research 80, 217-238.

Pimentel, M.M., Fuck, R.A., Botelho, N.F., 1999. Granites and the geodynamic history of the neoproterozoic Brasilia belt, central Brazil: a review. Lithos 46, $463-$ 483.

Pimentel, M.M., Fuck, R.A., Gioia, S.M.C.L., 2000. The Neoproterozoic Goiais maamatic Arc, central Brazil: a review and new Sm-Nd isotopic data. Revista Brasileira de Geociencias 30(1), 35-39.

Queiroz, C.L., 2000, Evolucao Tectono-Estrutural dos Terrenos Granito- Greenstone Belt de Crixais, Brasil Central. PhD Thesis. Universidade de Brasilia, 208pp.

Seer, H.J., 1999, Evolucao tectonica dos Grupos Araxa, Ibia e Canastra na sinforma de Araxai, Araxai, Minas Gerais. PhD Thesis. Universidade de Brasilia, 268 pp.

Seer, H.J., Dardenne, M.A., 2000. Tectonostratigraphic terrane analysis on Neoproterozoic times: the case study of Araxai synform, Minas Gerais state, Brazil: Implications to the final collage of the Gondwanaland. Revista Brasileira de Geociencias 30(1), 78-81.

Seer, H.J., Dardenne, M.A., Fonseca, M.A., 1999. O Grupo Ibiai na Sinforma de Araxa: Um terreno tectonoestratigrafico ligado a evolucao de arcos magmaticos. VII Simposio de Geologia do Centro-Oeste e X Simpósio de Geologia de Minas Gerais, Brasília, Boletim de Resumos, SBG-DF/MG/CO, p. 19.

Troger, U., Costa, J.F.G., Haesbaert, F.F., Zschocke, A., 1999. Novas contribuições aos aquíferos termais de Caldas Novas. VII Simposio de Geologia do CentroOeste e X Simposio de Geologia de Minas Gerais, Brasília, Boletim de Resumos, SBG-DF/MG/CO, p. 131.

Valeriano, C.de M., Teixeira, W., Heilbron, M., Simoes, L.S.de A., 2000. Southern Brasilia belt (SE Brazil): tectonic discontinuities, K-Ar data and evolution during the Neoproterozoic Brasiliano orogeny. Revista Brasileira de Geociencias 30(1), 195199.

Zschocke, A., 2000, Zur Hydrochemie der Grundwasser von Caldas NovasZentralbrasilien-Implikationen für das Thermalgrundwasser. MSc dissertation. Technical University of Berlin, Germany, 67 pp. 
